\title{
Tracking the Origin and Early Evolution of Reptiles
}

\author{
Lorenzo Marchetti ${ }^{*}$, Sebastian Voigt ${ }^{2}$, Michael Buchwitz ${ }^{3}$, Mark J. MacDougall', \\ Spencer G. Lucas ${ }^{4}$, David L. Fillmore ${ }^{5}$, Matthew R. Stimson ${ }^{6,7}$, Olivia A. King ${ }^{6,7}$, \\ John H. Calder ${ }^{7,8}$ and Jörg Fröbisch ${ }^{1,9}$
}

\begin{abstract}
${ }^{1}$ Museum für Naturkunde Berlin, Leibniz-Institut für Evolutions- und Biodiversitätsforschung, Berlin, Germany, 2 Urweltmuseum GEOSKOP/Burg Lichtenberg (Pfalz), Thallichtenberg, Germany, ${ }^{3}$ Museum für Naturkunde Magdeburg, Magdeburg, Germany, ${ }^{4}$ New Mexico Museum of Natural History, Albuquerque, NM, United States, ${ }^{5}$ Department of Physical Sciences, Kutztown University of Pennsylvania, Kutztown, PA, United States, ${ }^{6}$ Steinhammer Paleontological Laboratories, Geology/Paleontology Section, Natural History Department, New Brunswick Museum, Saint John, NB, Canada, ${ }^{7}$ Department of Geology, Saint Mary's University, Halifax, NS, Canada, ${ }^{8}$ Nova Scotia Department of Natural Resources, Halifax, NS, Canada, ${ }^{9}$ Institut für Biologie, Humboldt-Universität zu Berlin, Berlin, Germany
\end{abstract}

\section{OPEN ACCESS}

Edited by:

Stefano Dominici,

University of Florence, Italy

Reviewed by:

Michael James Benton, University of Bristol, United Kingdom Jens Lallensack,

Liverpool John Moores University, United Kingdom

*Correspondence:

Lorenzo Marchetti lorenzo.marchetti@mfn.berlin

Specialty section:

This article was submitted to Paleontology,

a section of the journal

Frontiers in Ecology and Evolution

Received: 16 April 2021 Accepted: 21 May 2021

Published: 01 July 2021

Citation:

Marchetti L, Voigt S, Buchwitz M, MacDougall MJ, Lucas SG, Fillmore DL, Stimson MR, King OA,

Calder JH and Fröbisch J (2021) Tracking the Origin and Early Evolution

of Reptiles.

Front. Ecol. Evol. 9:696511. doi: 10.3389/fevo.2021.696511
The origin of Reptilia and the biostratigraphic and palaeobiogeographic distribution of its early representatives are still poorly understood. An independent source of information may come from the extensive Carboniferous footprint record of reptiles, which is arguably richer and more complete than the skeletal record. Nevertheless, previous studies often failed to provide useful information because they were based on poorly preserved material and/or characters non-exclusive of reptile tracks. In fact, a large part of the supposed early reptile tracks can be assigned to the anamniote ichnotaxon Hylopus hardingi. Here, we revise the ichnotaxon Hylopus hardingi based on anatomy-consistent material, attribute it to anamniote reptiliomorphs, and distinguish it from Notalacerta missouriensis, the earliest ichnotaxon that can be attributed to reptiles, and the somewhat younger Varanopus microdactylus (attributed to parareptiles, such as bolosaurians) and Dromopus lacertoides (attributed to araeoscelid reptiles and non-varanodontine varanopids). These attributions are based on correlating morphofunctional features of tracks and skeletons. Multivariate analysis of trackway parameters indicates that the late Bashkirian Notalacerta missouriensis and Hylopus hardingi differ markedly in their trackway patterns from Late Mississippian Hylopus hardingi and Late Pennsylvanian reptile tracks, which appear to share a derived amniote-like type of gait. While the first occurrence/appearance of reptile tracks in the tetrapod footprint record during the late Bashkirian corresponds to the first occurrence/appearance of reptiles in the skeletal record, footprints significantly enlarge the paleobiogeographic distribution of the group, suggesting an earlier radiation of reptiles during the Bashkirian throughout North America and possibly North Africa. Dromopus appeared in the Kasimovian together with the diapsid group Araeoscelidia, but footprints from Western-European occurrences enlarge the paleobiogeographic distribution of diapsids and varanopids. Varanopus and bolosaurian parareptiles appear in the Gzhelian of North America. Older parareptiles are, however, known from the late Moscovian. In all, the footprint record of early reptiles supplements the skeletal record, suggesting possible future lines of research. 


\section{INTRODUCTION}

The origin of reptiles has been consistently placed in the Carboniferous, and more specifically, a late Mississippian to Early Pennsylvanian origin of this group is inferred (e.g., Didier and Laurin, 2020; Pardo et al., 2020 and references therein). The skeletal record of the earliest reptiles is, however, rather incomplete, scattered and in need of revision (e.g., Mann et al., 2019). Moreover, the phylogeny of the earliest representatives of reptile groups is often unclear or not fully resolved, because of the overall similarity among these forms and the difficult distinction from closely related anamniote reptiliomorphs and synapsids (e.g., Ford and Benson, 2020). An independent source of information may come from the tetrapod footprint record, especially as regards the palaeoecology, biostratigraphic and palaeobiogeographic distribution of reptile groups. Moreover, fossil footprints can provide clues to potential interrelationships among trackmaker groups that, however, can only be verified through the phylogenetic study of the skeletal record. Tetrapod footprints are a valuable source of information for tetrapod groups, provided that a sound anatomy-consistent ichnotaxonomy and track-trackmaker correlation have been established (e.g., Haubold et al., 1995; Voigt et al., 2007; Marchetti et al., 2019a,b). The tetrapod footprint record of the Carboniferous is generally more extensive than the skeletal record (e.g., Lucas, 2019). Therefore, hypotheses about the origin of reptiles can benefit from the inclusion of data obtained from the footprint record. Nevertheless, recent revision studies based on anatomy-consistent approaches are few (e.g., Voigt and Ganzelewski, 2010; Buchwitz and Voigt, 2018; Marchetti et al., 2020a), and most material is in need of revision. This has caused misinterpretations of the tetrapod footprint record, especially with regard to the origin of reptiles. In fact, the morphology of early reptile tracks and contemporary anamniote reptiliomorphs can be very similar and is easily misinterpreted without a thorough ichnotaxonomic study. This is especially the case with the ichnotaxon Hylopus hardingi, probably an anamniote reptiliomorph track type. Material assignable to this ichnotaxon is often erroneously assigned and mistaken for a reptile track (e.g., Falcon-Lang et al., 2007; Marchetti et al., 2019a, 2020a). Thus, in order to clarify the origin of reptiles in the tetrapod footprint record, a thorough revision of this ichnotaxon is necessary, as well as a detailed study of the earliest reptile ichnotaxa and their trackmakers. In this work, we comprehensively revise Hylopus hardingi and compare it to the early reptile ichnospecies Notalacerta missouriensis, Varanopus microdactylus, and Dromopus lacertoides. A tracktrackmaker correlation based on morphofunctional features of tracks and skeletons is then proposed for these four ichnotaxa. Multivariate analysis has been carried out for Late CarboniferousCisuralian reptile tracks and the anamniote reptiliomorph track Hylopus, in order to infer trends in the evolution of locomotor capabilities of the alleged trackmaker groups. In addition, considerations of the stratigraphic distribution and paleobiogeography of both the earliest reptile footprints and skeletons are proposed.

\section{MATERIALS AND METHODS}

\section{Ichnological Study}

The tetrapod footprint material has been studied first-hand whenever possible and photographed with a digital camera perpendicular to the footprint surface when illuminated by artificial oblique light. Some relevant specimens were drawn on transparent film and later digitized. All the specimens were evaluated by means of the morphological preservation scale/rating of Marchetti et al. (2019a). Only well-preserved footprints (preservation grade 2.0-3.0) and, when possible, trackways, have been considered relevant to our ichnotaxonomic study. These specimens record the anatomy-consistent features of footprints, which are used as diagnostic characters for the assignment, and they have not been altered substantially due to substrate characteristics, such as water saturation, cohesiveness and grain size spectrum or by secondary behavior of the trackmaker, such as sliding, limping, etc. These substrate and behavioral factors can produce morphological features unrelated to or inconsistent with the trackmaker anatomy, generally known as extramorphologies sensu Peabody (1948) and Haubold et al. (1995).

The tetrapod track measurements listed in Tables 1-3 were taken with specific software (e.g., Gimp $2^{\circledR}$ ) and mostly follow the conventions of Leonardi (1987). 3D models were obtained through digital photogrammetry with the software Agisoft Photoscan Professional ${ }^{\circledR}$ (v.1.4.0). Contour lines and color depth maps were obtained by employing the software Cloud Compare ${ }^{\circledR}$ (v.2.8 beta) and Paraview ${ }^{\circledR}$ (v.4.1.0).

The track-trackmaker correlations were based on morphofunctional features that tracks and postcranial skeletons of the potential trackmakers have in common (e.g., Voigt et al., 2007; Marchetti et al., 2017, 2019b, 2020b). These morphological features in tracks do not have a cladistic meaning, but instead have a precise functional and morphometric meaning that is caused by specific functional and morphometric features of the trackmaker postcranial skeletons, and this may have instead a cladistic meaning (e.g., Carrano and Wilson, 2001). In fact, ichnotaxonomy is a parataxonomy parallel to the phylogenetic classification of the producers, so any relationship to clades is not an actual assignment but rather a correlation. Notwithstanding, these track features can still be the subject of character evolution studies based on preexisting trackmaker phylogenies (e.g., Buchwitz et al., 2021). In our discussion of producer groups for reptile tracks, we follow the phylogenetic analysis of Ford and Benson (2020), whose results indicate that varanopids were a group of reptiles, although most other hypotheses have grouped varanopids within synapsids (e.g., Reisz and Dilkes, 2003; Berman et al., 2014; Spindler et al., 2018). The term "Reptiliomorpha" is used here according to the temnospondyl hypothesis of lissamphibian ancestry (sensu Ruta et al., 2003; Ruta and Coates, 2007) and groups of early tetrapods presumably more closely related to amniotes than temnospondyls are referred to as "anamniote reptiliomorphs" here. 
TABLE 1 | Ichnological parameters of pedal footprints.

\begin{tabular}{|c|c|c|c|c|c|c|c|c|c|c|c|c|c|c|c|c|c|c|c|c|}
\hline Ichnotaxon & $\mathbf{N}$ & $\operatorname{Tr}$ & Formation & Age & State & FL & FW & FL/FW & psL & psW & I L & II L & III L & IV L & $\mathbf{V} \mathbf{L}$ & div I-II & div II-III & div III-IV & $\operatorname{div}$ IV-V & div \\
\hline \multirow[t]{2}{*}{$\begin{array}{l}\text { Dromopus } \\
\text { lacertoides }\end{array}$} & $\begin{array}{l}\text { NSM } 009 \text { GF } \\
012\end{array}$ & & Cape John & $\begin{array}{l}\text { Gzhelian- } \\
\text { Asselian }\end{array}$ & Nova Scotia & 43.8 & 35.7 & 1.2 & & & & 14.1 & 23.4 & 31.8 & 17.2 & & 38 & 16.2 & 44.3 & \\
\hline & YPM 519 & & $\begin{array}{l}\text { Howard } \\
\text { Limestone }\end{array}$ & Gzhelian & Kansas & 75.2 & 67.3 & 1.1 & 19.2 & 24.9 & 22.4 & 26.8 & 37.2 & 54.2 & 33 & 19.3 & 27.1 & 23.6 & 62.6 & 132.6 \\
\hline \multirow[t]{2}{*}{$\begin{array}{l}\text { Varanopus } \\
\text { microdactylus }\end{array}$} & $\begin{array}{l}\text { NSM } 997 \text { GF } \\
30.6\end{array}$ & & Cape John & $\begin{array}{l}\text { Gzhelian- } \\
\text { Asselian }\end{array}$ & Nova Scotia & 24.9 & 26.6 & 0.9 & 8.5 & 13.3 & 8 & 11.2 & 15.5 & 17.9 & 12.4 & 21.3 & 18.3 & 17.4 & 39.6 & 96.6 \\
\hline & $\begin{array}{l}\text { NSM } 99 \text { GF } \\
34 b\end{array}$ & & Cape John & $\begin{array}{l}\text { Gzhelian- } \\
\text { Asselian }\end{array}$ & Nova Scotia & 36.3 & 30.7 & 1.2 & 13.1 & 17.9 & 9.1 & 13.7 & 19.6 & 23.4 & 14.9 & 18.9 & 11.9 & 10.5 & 45.2 & 86.5 \\
\hline \multirow[t]{12}{*}{$\begin{array}{l}\text { Notalacerta } \\
\text { missouriensis }\end{array}$} & USNM 7321 & & Chanute & $\begin{array}{l}\text { Late } \\
\text { Kasimovian }\end{array}$ & Missouri & 24.0 & 30.3 & 0.8 & 10.7 & 14.7 & 7.3 & 10.1 & 14.1 & 18.2 & 10.7 & 35.1 & 14.9 & 19.8 & 40.8 & 110.5 \\
\hline & $\begin{array}{l}\text { NMMNH P } \\
31705\end{array}$ & & McAlester & Late Moscovian & Oklahoma & 20.2 & 22.7 & 0.9 & 6.4 & 12.4 & 5.9 & 8.3 & 12.0 & 15.2 & 10.4 & 19.9 & 26.5 & 19.4 & 36.9 & 102.7 \\
\hline & $\begin{array}{l}\text { NMMNH P } \\
31746-7\end{array}$ & & McAlester & Late Moscovian & Oklahoma & 17.6 & 22.2 & 0.8 & 6.1 & 8.9 & 5.4 & 8.3 & 10.9 & 14.0 & 10.0 & 27.5 & 15.7 & 24.4 & 26.9 & 94.5 \\
\hline & $\begin{array}{l}\text { NMMNH P } \\
31749\end{array}$ & & McAlester & Late Moscovian & Oklahoma & 17.9 & 20.2 & 0.9 & 6.0 & 10.6 & 5.0 & 7.5 & 10.4 & 13.9 & 8.9 & 31.9 & 21.4 & 23.2 & 31.0 & 107.5 \\
\hline & $\begin{array}{l}\text { NMMNH P } \\
31751\end{array}$ & & McAlester & Late Moscovian & Oklahoma & 14.8 & 19.1 & 0.8 & & & 3.9 & 6.8 & 9.2 & 12.2 & 8.3 & 24.2 & 28.7 & 27.4 & 31.4 & 111.7 \\
\hline & $\begin{array}{l}\text { NMMNH P } \\
31759-61\end{array}$ & & McAlester & Late Moscovian & Oklahoma & 16.2 & 20.6 & 0.8 & 5.0 & 9.9 & 4.9 & 7.9 & 11.0 & 13.9 & 9.1 & 25.4 & 21.2 & 21.4 & 31.9 & 99.9 \\
\hline & $\begin{array}{l}\text { NSM } \\
\text { 008GF031.068 }\end{array}$ & & Joggins & Late Bashkirian & Nova Scotia & 30 & 31.3 & 1.0 & 12.4 & 16.8 & & 8.5 & 13.8 & 17.1 & & 31.53 & 26.57 & 6.43 & & \\
\hline & KGS 1381 & & Lee & Late Bashkirian & Kentucky & 38.1 & 31.4 & 1.2 & 11.1 & & 9.5 & 15.2 & 21.2 & 29.9 & 20.2 & 18.8 & 10.6 & 13.1 & 24.5 & 67.0 \\
\hline & UGKU 1914 & & Pottsville & Late Bashkirian & Alabama & 18.8 & 15.8 & 1.2 & 7.5 & 9.5 & 5.6 & 7.7 & 10.8 & 12 & 9.2 & 12.9 & 13.3 & 35.4 & 55.9 & 117.5 \\
\hline & JL-NN 1 & 1 & Pottsville & Late Bashkirian & Alabama & 19.9 & 18.5 & 1.1 & 6.1 & 12.4 & 5.5 & 7 & 11.2 & 14.5 & 12.4 & 13.5 & 12.6 & 10.7 & 38.6 & 75.4 \\
\hline & & 2 & & & & 21.5 & 20.7 & 1.0 & 6.1 & 11.9 & 6.1 & 7.7 & 12.7 & 16.1 & 14.1 & 12.6 & 14.2 & 10.2 & 42.5 & 79.5 \\
\hline & & 3 & & & & 20.9 & 18.9 & 1.1 & 6.1 & & 7.2 & 8.2 & 11.1 & 15.2 & 12.7 & 14.1 & 24.2 & 13.2 & 38.8 & 90.3 \\
\hline \multirow[t]{9}{*}{$\begin{array}{l}\text { Hylopus } \\
\text { hardingi }\end{array}$} & SGM SA & & Sulzbach & $\begin{array}{l}\text { Early } \\
\text { Moscovian }\end{array}$ & Germany & 106.7 & 84.4 & 1.3 & 50.2 & 48.1 & 29 & 40.7 & 56.4 & 62.5 & 44.2 & 7.5 & 8.5 & 20.6 & 65.3 & 101.9 \\
\hline & $\begin{array}{l}\text { NSM } \\
\text { 008GF039.039 }\end{array}$ & & Joggins & Late Bashkirian & Nova Scotia & 48.3 & 60.2 & 0.8 & 18.5 & 35.1 & 11.6 & 20.4 & 29.9 & 31.2 & 25.1 & 22.7 & 9.3 & 28.7 & 20.2 & 80.9 \\
\hline & $\begin{array}{l}\text { NSM } \\
\text { 010GF045.051 }\end{array}$ & & Joggins & Late Bashkirian & Nova Scotia & 40.3 & 53 & 0.8 & & & 9.7 & 11.4 & 24.4 & 32.5 & & 77.43 & 12.13 & 16.51 & & \\
\hline & NBMG 14143 & & Grande Anse & Late Bashkirian & New Brunswick & 58 & 55.7 & 1.0 & 22 & 36.2 & 17.6 & 22.7 & 25.8 & 33.2 & 24.2 & 30.9 & 16.7 & 28 & 15.3 & 90.9 \\
\hline & NBMG 3060 & & Parrsboro & early Bashkirian & Nova Scotia & 38.8 & 32.3 & 1.2 & 17.3 & 19.4 & 9.2 & 14.8 & 19.9 & 25.2 & 17.4 & 14.3 & 20 & 19.5 & 38.1 & 91.9 \\
\hline & MCZ 267 & & West Bay & $\begin{array}{l}\text { Late } \\
\text { Mississippian }\end{array}$ & Nova Scotia & 102.1 & 94.1 & 1.1 & 57.5 & 57.3 & & 30.6 & 41.3 & 55 & 35.6 & & 33.8 & 13.4 & 54.4 & \\
\hline & YPM-PU 16983 & & West Bay & $\begin{array}{l}\text { Late } \\
\text { Mississippian }\end{array}$ & Nova Scotia & 48.9 & 63.7 & 0.8 & 17.8 & 35.9 & 12.5 & 24.2 & 26.4 & 32.7 & 21.9 & -19.86 & 19.11 & 22.12 & 64.56 & 85.9 \\
\hline & YPM-PU 18828 & & Pomquet & $\begin{array}{l}\text { Late } \\
\text { Mississippian }\end{array}$ & Nova Scotia & 44.7 & 56.2 & 0.8 & 17 & 29.8 & 14.3 & 17.7 & 23.4 & 30.3 & 23.7 & 54.18 & 17.03 & 8.44 & 57.34 & 137.0 \\
\hline & ANSP 22651 & & Mauch Chunk & $\begin{array}{l}\text { Late } \\
\text { Mississippian }\end{array}$ & Pennsylvania & 24.6 & 33 & 0.7 & 10.2 & 17.2 & 10.3 & 14.9 & 16.8 & 19.2 & 15.1 & -0.6 & 16.8 & 20.8 & 54.9 & 91.9 \\
\hline
\end{tabular}




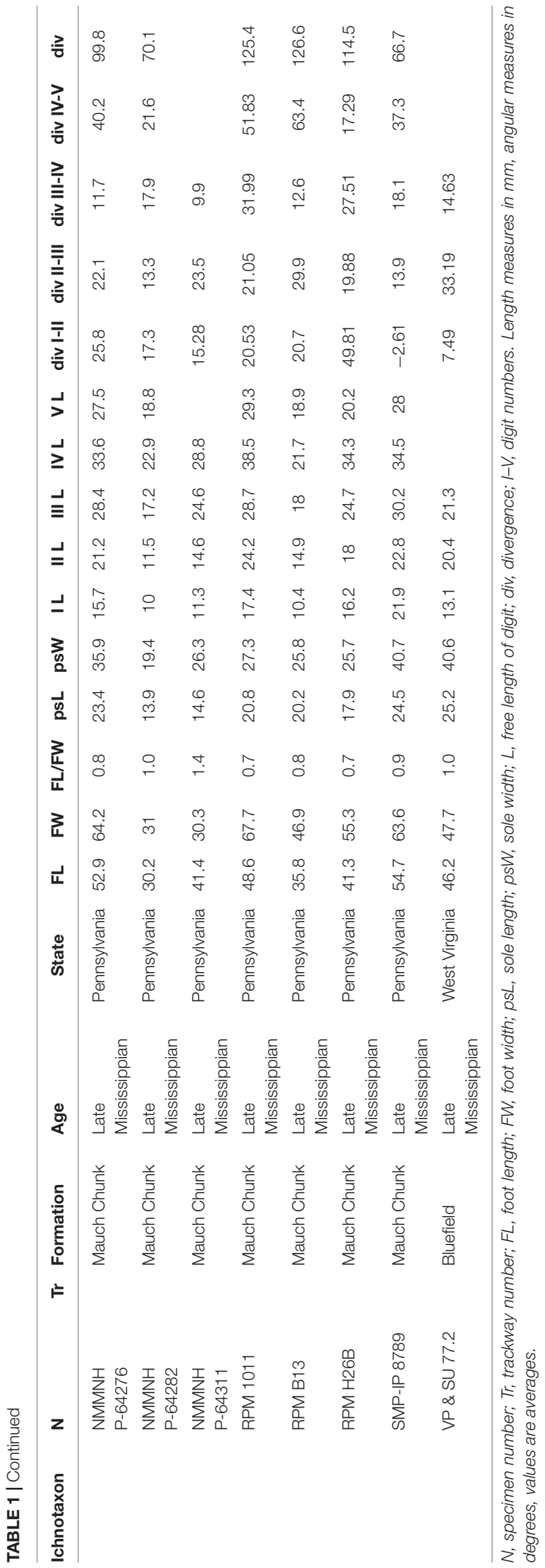

\section{Multivariate Analysis}

To define their degree of similarity and whether they can be separated based on standard imprint and trackway measurements (Table 3 and Supplementary Material), we compare the following Late Mississipian and Pennsylvanian samples of alleged anamniote reptiliomorph and reptile tracks in a multivariate approach (employing the statistics software package PAST 3 and 4.05; Hammer et al., 2001): ten trackways of Hylopus hardingi from Late Mississippian deposits of Pennsylvania, West Virginia and Nova Scotia (e.g., Sundberg et al., 1990; Fillmore et al., 2012; this work) and one trackway from early Bashkirian deposits of Nova Scotia (e.g., Sternberg, 1933); three trackways of Hylopus hardingi from late Bashkirian strata of New Brunswick and Nova Scotia (e.g., Falcon-Lang et al., 2007; this work); six trackways of Notalacerta missouriensis from late Bashkirian units of Alabama, Kentucky and Nova Scotia (e.g., Chesnut et al., 1994; Haubold et al., 2005; Marchetti et al., 2020a); and five trackways of Notalacerta missouriensis from deposits of the McAlester Formation of Oklahoma, which have a Moscovian age (e.g., Lucas et al., 2004; Marchetti et al., 2020a). Four trackways of Gzhelian age from Kansas and Nova Scotia (e.g., Marsh, 1894; Van Allen et al., 2005), which have been assigned to Dromopus lacertoides and Varanopus microdactylus, and one Hylopus hardingi trackway (specimen SGM SA) from the Moscovian of Germany (e.g., Voigt, 2007) are included as individual samples. Further trackways of Hylopus hardingi and cf. Hylopus isp. have been measured (Table 3) but are not considered here because their morphological preservation is not sufficient to define the (total) pes length.

Because the sample sizes of Late Pennsylvanian Varanopus microdactylus and Dromopus lacertoides are too small for the purpose of inferring group characteristics for these two ichnotaxa and to compare them with the older Notalacerta missouriensis records, we broaden the database. We include five trackways of Varanopus microdactylus and 12 trackways of Dromopus lacertoides from the Cisuralian of the Thuringian Forest (data from Voigt, 2005). Accordingly, we consider two different test cases: (1) four groups of Mississippian to Moscovian anamiote reptiliomorph and reptilian tracks (Mississippianearly Bashkirian Hylopus, late Bashkirian Hylopus, Bashkirian Notalacerta, Moscovian Notalacerta) plus five individual trackways (Gzhelian Dromopus, Gzhelian Varanopus, Moscovian Hylopus) and (2) four groups of Bashkirian to Cisuralian reptile tracks (Bashkirian Notalacerta, Moscovian Notalacerta, Gzhelian-Cisuralian Dromopus, Gzhelian-Cisuralian Varanopus).

We use pes length as a body size proxy for the normalization of length measures, such as stride length, pace length, gauge width, pes-manus distance and "apparent trunk length" (glenoacetabular length sensu Leonardi, 1987, formula for walking trot), as a standard procedure to eliminate body size as a cause of variation. Four normalized length measuresnormalized pedal stride length, normalized pedal gauge width, normalized difference between manual and pedal gauge width and normalized distance between pes and manus parallel to the trackway midline-and two angles-the orientation of the pes with respect to the trackway midline and the 
TABLE 2 | Ichnological parameters of manual footprints.

\begin{tabular}{|c|c|c|c|c|c|c|c|c|c|c|c|c|c|c|c|c|c|c|c|c|c|}
\hline & $\mathbf{N}$ & $\operatorname{Tr}$ & Formation & Age & State & FL & FW & FL/FW & psL & psW & IL & II L & III L & IV L & $\mathbf{V} \mathbf{L}$ & div I-II & div II-III & div III-IV & div IV-V & div & FLp/FLm \\
\hline \multirow[t]{2}{*}{$\begin{array}{l}\text { Dromopus } \\
\text { lacertoides }\end{array}$} & $\begin{array}{l}\text { NSM } 009 \text { GF } \\
012\end{array}$ & & Cape John & $\begin{array}{l}\text { Gzhelian- } \\
\text { Asselian }\end{array}$ & Nova Scotia & 37 & 27.3 & 1.4 & 7.2 & 11.4 & 9.2 & 13.1 & 19.8 & 24.8 & 15.3 & 23 & 31.8 & 18 & 91.2 & 164.0 & 1.2 \\
\hline & YPM 519 & & $\begin{array}{l}\text { Howard } \\
\text { Limestone }\end{array}$ & Gzhelian & Kansas & 59.9 & 43.8 & 1.4 & 13 & 17.4 & 15 & 18.9 & 29.6 & 42.1 & 20.4 & 19.9 & 21.2 & 24.8 & 74.6 & 140.5 & 1.3 \\
\hline \multirow[t]{2}{*}{$\begin{array}{l}\text { Varanopus } \\
\text { microdactylus }\end{array}$} & $\begin{array}{l}\text { NSM } 997 \text { GF } \\
30.6\end{array}$ & & Cape John & $\begin{array}{l}\text { Gzhelian- } \\
\text { Asselian }\end{array}$ & Nova Scotia & 19.2 & 24.5 & 0.8 & 6.8 & 10.9 & 8.3 & 10.4 & 12.3 & 13.9 & 7.9 & 19.7 & 25.2 & 27.3 & 48 & 120.2 & 1.3 \\
\hline & $\begin{array}{l}\text { NSM } 99 \text { GF } \\
34 \mathrm{~b}\end{array}$ & & Cape John & $\begin{array}{l}\text { Gzhelian- } \\
\text { Asselian }\end{array}$ & Nova Scotia & 28.1 & 28.7 & 1.0 & 10.6 & 15 & 6.6 & 11.2 & 14.5 & 19.4 & 10.9 & 23.1 & 11 & 19.1 & 41.3 & 94.5 & 1.3 \\
\hline \multirow[t]{12}{*}{$\begin{array}{l}\text { Notalacerta } \\
\text { missouriensis }\end{array}$} & USNM 7321 & & Chanute & $\begin{array}{l}\text { Late } \\
\text { Kasimovian }\end{array}$ & Missouri & 23.7 & 24.4 & 1.0 & 7.6 & 8.5 & 7.9 & 10.6 & 13.0 & 16.6 & 10.5 & 26.5 & 30.0 & 11.2 & 50.8 & 118.5 & 1.0 \\
\hline & $\begin{array}{l}\text { NMMNH P } \\
31705\end{array}$ & & McAlester & Late Moscovian & Oklahoma & 15.9 & 15.4 & 1.0 & 5.5 & 7.8 & 4.5 & 6.7 & 10.1 & 11.9 & 6.1 & 22.2 & 20.0 & 23.6 & 39.2 & 104.9 & 1.3 \\
\hline & $\begin{array}{l}\text { NMMNH P } \\
31746-7\end{array}$ & & McAlester & Late Moscovian & Oklahoma & 13.9 & 15.3 & 0.9 & 5.1 & 8.6 & 3.1 & 6.1 & 9.9 & 10.7 & 4.9 & 19.3 & 26.9 & 17.5 & 47.3 & 111.0 & 1.3 \\
\hline & $\begin{array}{l}\text { NMMNH P } \\
31749\end{array}$ & & McAlester & Late Moscovian & Oklahoma & 13.9 & 15.3 & 0.9 & 4.4 & 6.0 & 4.1 & 6.6 & 9.1 & 10.2 & 6.5 & 37.2 & 29.8 & 16.2 & 51.0 & 134.2 & 1.3 \\
\hline & $\begin{array}{l}\text { NMMNH P } \\
31751\end{array}$ & & McAlester & Late Moscovian & Oklahoma & 11.1 & 14.3 & 0.8 & & & 4.8 & 5.9 & 6.7 & 6.9 & 3.8 & 27.6 & 23.8 & 30.9 & 45.8 & 128.1 & 1.3 \\
\hline & $\begin{array}{l}\text { NMMNH P } \\
31759-61\end{array}$ & & McAlester & Late Moscovian & Oklahoma & 12.6 & 14.6 & 0.9 & 3.8 & 7.3 & 3.2 & 5.7 & 8.2 & 9.5 & 4.6 & 46.2 & 25.7 & 17.6 & 52.1 & 141.6 & 1.3 \\
\hline & $\begin{array}{l}\text { NSM } \\
\text { 008GF031.068 }\end{array}$ & & Joggins & late Bashkirian & Nova Scotia & 23.4 & 27.6 & 0.8 & 9.7 & 13.4 & 6.9 & 8.9 & 13 & 16.4 & 11.7 & 29.8 & 22.1 & 32.1 & 42 & 126.0 & 1.3 \\
\hline & KGS 1381 & & Lee & Late Bashkirian & Kentucky & 27.3 & 22.3 & 1.2 & 11 & 14.4 & 6.1 & 11.2 & 15.3 & 19 & 9 & 20.9 & 8.2 & 20.8 & 33 & 82.9 & 1.4 \\
\hline & UGKU 1914 & & Pottsville & Late Bashkirian & Alabama & 16.3 & 16.5 & 1.0 & 5.5 & 8.8 & 5.1 & 7.3 & 10 & 12 & 6.8 & 9.4 & 28.1 & 18.1 & 49.6 & 105.2 & 1.2 \\
\hline & JL-NN 1 & 1 & Pottsville & Late Bashkirian & Alabama & 13.8 & 13.3 & 1.0 & 5.6 & 7.9 & 2.9 & 4.9 & 7.7 & 9.6 & 6.6 & 46.4 & 9.4 & 11.4 & 35.4 & 102.6 & 1.4 \\
\hline & & 2 & & & & 14.6 & 16.1 & 0.9 & 4.9 & 8.7 & 3.3 & 5.4 & 8.6 & 10.8 & 6.5 & 27.1 & 16.5 & 25 & 38.2 & 106.8 & 1.5 \\
\hline & & 3 & & & & 13.8 & 21.1 & 0.7 & 5.8 & 10 & 5.6 & 5.8 & 7.5 & 7.5 & 6.7 & 21.16 & 28.9 & 0 & 61.31 & 111.4 & 1.5 \\
\hline \multirow[t]{8}{*}{$\begin{array}{l}\text { Hylopus } \\
\text { hardingi }\end{array}$} & SGM SA & & Sulzbach & $\begin{array}{l}\text { Early } \\
\text { Moscovian }\end{array}$ & Germany & 46.4 & 46.9 & 1.0 & & & 14.7 & 24.9 & 30.1 & 27.8 & & 26.2 & 25.1 & 18 & & & 2.3 \\
\hline & $\begin{array}{l}\text { NSM } \\
\text { 008GF031.142 }\end{array}$ & & Joggins & Late Bashkirian & Nova Scotia & 21.3 & 33.5 & 0.6 & 8.6 & 24.7 & 6.6 & 10.7 & 13.1 & 15.7 & 9.7 & 34.96 & 14.51 & 40.17 & 40.89 & 130.5 & \\
\hline & $\begin{array}{l}\text { NSM } \\
\text { 008GF039.039 }\end{array}$ & & Joggins & Late Bashkirian & Nova Scotia & 29.9 & 40.6 & 0.7 & 10.3 & 19 & 8.8 & 14.2 & 20.8 & 26 & 18.8 & 13.78 & 33.58 & 35.57 & 37 & 119.9 & 1.6 \\
\hline & $\begin{array}{l}\text { NSM } \\
\text { 008GF039.336 }\end{array}$ & & Joggins & Late Bashkirian & Nova Scotia & 25 & 29.1 & 0.9 & 9 & 12.4 & 5.1 & 10.3 & 16 & 18.5 & 10.8 & 52.68 & 25.3 & 37.34 & 51.72 & 167.0 & \\
\hline & $\begin{array}{l}\text { NSM } \\
\text { 010GF045.051 }\end{array}$ & & Joggins & Late Bashkirian & Nova Scotia & 38.6 & 41.8 & 0.9 & 18.3 & 24.6 & 12.8 & 14.2 & 18.7 & 23.9 & 14.8 & 28.5 & 36.2 & 32.5 & 34.4 & 131.6 & 1.0 \\
\hline & NBMG 14143 & & Grande Anse & Late Bashkirian & New Brunswick & 45.6 & 44.1 & 1.0 & 17.4 & 26.7 & 10.5 & 14.7 & 20.4 & 29.5 & 17.1 & 24.9 & 11.4 & 18.7 & 51.9 & 106.9 & 1.3 \\
\hline & UCM 263 JT & & Pottsville & Late Bashkirian & Alabama & 38.1 & 37.7 & 1.0 & 13.6 & 15.4 & 9.7 & 19.4 & 24.7 & 27.5 & 17.4 & 16.8 & 26.4 & 34 & 44 & 121.2 & \\
\hline & NBMG 3060 & & Parrsboro & Early Bashkirian & Nova Scotia & 29.6 & 31.9 & 0.9 & 11.2 & 20 & 6.3 & 10.9 & 17.4 & 21.7 & 9.8 & 6.7 & 16.5 & 19.8 & 34.1 & 77.1 & 1.3 \\
\hline
\end{tabular}


TABLE 2 | Continued

\begin{tabular}{|c|c|c|c|c|c|c|c|c|c|c|c|c|c|c|c|c|c|c|c|c|c|}
\hline & $\mathrm{N}$ & $\operatorname{Tr}$ & Formation & Age & State & FL & FW & FL/FW & psL & psW & IL & II L & III L & IV L & V L & div I-II & div II-III & div III-IV & div IV-V & div & FLp/FLm \\
\hline & MCZ 267 & & West Bay & $\begin{array}{l}\text { Late } \\
\text { Mississippian }\end{array}$ & Nova Scotia & 59.5 & 78.2 & 0.8 & 25.2 & 44.4 & 14.9 & 30.6 & 36.7 & 43.1 & 27.8 & 14.5 & 39.1 & 31.7 & 39.3 & 124.6 & 1.7 \\
\hline & YPM-PU 16983 & & West Bay & $\begin{array}{l}\text { Late } \\
\text { Mississippian }\end{array}$ & Nova Scotia & 34.8 & 39.6 & 0.9 & 13 & 25.6 & 12.2 & 16.5 & 19.5 & 22.1 & 16.1 & 28.8 & 9.19 & 23.75 & 67.95 & 129.7 & 1.4 \\
\hline & YPM-PU 18828 & & Pomquet & $\begin{array}{l}\text { Late } \\
\text { Mississippian }\end{array}$ & Nova Scotia & 29.3 & 42.2 & 0.7 & 10.2 & 22.2 & 9.4 & 15.2 & 19.8 & 25.3 & & 40.57 & 21.71 & 38.23 & & & 1.5 \\
\hline & NBMG 10128 & & Enrage & $\begin{array}{l}\text { Late } \\
\text { Mississippian }\end{array}$ & New Brunswick & 40 & 40.1 & 1.0 & 17.9 & 30.7 & 13.1 & 14.8 & 20.3 & 26.8 & & 21.3 & 18.4 & 26 & & & \\
\hline & ANSP 22651 & & Mauch Chunk & $\begin{array}{l}\text { Late } \\
\text { Mississippian }\end{array}$ & Pennsylvania & 25.3 & 28.8 & 0.9 & 9.8 & 14.9 & 9.1 & 10.5 & 14.2 & 17.5 & 11.6 & 11.2 & 25.7 & 26.9 & 38.2 & 102.0 & 1.0 \\
\hline & $\begin{array}{l}\text { NMMNH } \\
\text { P-64276 }\end{array}$ & & Mauch Chunk & $\begin{array}{l}\text { Late } \\
\text { Mississippian }\end{array}$ & Pennsylvania & 43.3 & 50.3 & 0.9 & 17.2 & 29.6 & 12.7 & 18.6 & 26 & 32.6 & 15.2 & 20.2 & 16.6 & 29.4 & 45.8 & 112.0 & 1.2 \\
\hline & $\begin{array}{l}\text { NMMNH } \\
\text { P-64282 }\end{array}$ & & Mauch Chunk & $\begin{array}{l}\text { Late } \\
\text { Mississippian }\end{array}$ & Pennsylvania & 26.3 & 24 & 1.1 & 9.5 & 12.4 & 8.5 & 10.8 & 13.5 & 17.8 & 8.2 & 16.4 & 28 & 14 & 32.2 & 90.6 & 1.1 \\
\hline & $\begin{array}{l}\text { NMMNH } \\
\text { P-64311 }\end{array}$ & & Mauch Chunk & $\begin{array}{l}\text { Late } \\
\text { Mississippian }\end{array}$ & Pennsylvania & 36.1 & 32.5 & 1.1 & 13.3 & 18.6 & 10.6 & 12.3 & 17.7 & 25.2 & 15.7 & 21.4 & 37.3 & 27.1 & 19.6 & 105.4 & 1.1 \\
\hline & RPM 1011 & & Mauch Chunk & $\begin{array}{l}\text { Late } \\
\text { Mississippian }\end{array}$ & Pennsylvania & 44.8 & 50.6 & 0.9 & 18.3 & 23.4 & 12.5 & 21.5 & 25.5 & 33.4 & 24.7 & 19.9 & 20.6 & 35.64 & 40.57 & 116.7 & 1.1 \\
\hline & RPM B13 & & Mauch Chunk & $\begin{array}{l}\text { Late } \\
\text { Mississippian }\end{array}$ & Pennsylvania & 29.9 & 30.2 & 1.0 & & & & 13 & 18.5 & 23.5 & 8.5 & & 15.9 & 29.2 & 50.9 & & 1.2 \\
\hline & RPM H26B & & Mauch Chunk & $\begin{array}{l}\text { Late } \\
\text { Mississippian }\end{array}$ & Pennsylvania & 32.9 & 41.1 & 0.8 & & & 11.7 & 16.2 & 20 & 25.9 & & 18.6 & 36.04 & 31.92 & & & 1.3 \\
\hline & SMP-IP 8789 & & Mauch Chunk & $\begin{array}{l}\text { Late } \\
\text { Mississippian }\end{array}$ & Pennsylvania & 41.6 & 49.8 & 0.8 & 16.5 & 28.5 & 13.2 & 16.6 & 22.4 & 29 & 18.5 & 28.3 & 25.2 & 23.4 & 37.7 & 114.6 & 1.3 \\
\hline & VP \& SU 77.1 & & Bluefield & $\begin{array}{l}\text { Late } \\
\text { Mississippian }\end{array}$ & West Virginia & 34.8 & 37.7 & 0.9 & 16.9 & 19.3 & 9.4 & 9.9 & 18.2 & 25.3 & 16.3 & 58.9 & 41.8 & 32.7 & 35.8 & 169.2 & 1.3 \\
\hline cf. Hylopus isp. & $\begin{array}{l}\text { ALMNH } \\
\text { P.985.1.7. }\end{array}$ & & Pottsville & Late Bashkirian & Alabama & 26.6 & 27.9 & 1.0 & 7.2 & 13.5 & 5.3 & 10.7 & 15.8 & 19.4 & 12.9 & 35 & 31.7 & 19.3 & 32.1 & 118.1 & 1.1 \\
\hline
\end{tabular}

$N$, specimen number; Tr, trackway number; FL, foot length; FW, foot width; psL, sole length; psW, sole width; L, free length of digit; div, divergence; I-V, digit number; FLp/FLm, foot length pes/foot length manus ratio. Length measures in $\mathrm{mm}$, angular measures in degrees, values are averages. 
TABLE 3 | Ichnological parameters of vertebrate trackways.

\begin{tabular}{|c|c|c|c|c|c|c|c|c|c|c|c|c|c|c|c|c|c|c|c|c|c|}
\hline & $\mathbf{N}$ & Tr Formation & Age & State & SLp & PLp & PAp & LPp & WPp & DIVp & SLm & PLm & PAm & LPm & WPm & DIVm & Dmp & BL & SLp/FL & WPp/FL & $\mathrm{BL} / \mathrm{FL}$ \\
\hline \multirow[t]{2}{*}{$\begin{array}{l}\text { Dromopus } \\
\text { lacertoides }\end{array}$} & $\begin{array}{l}\text { NSM } 009 \text { GF } \\
012\end{array}$ & Cape John & $\begin{array}{l}\text { Gzhelian- } \\
\text { Asselian }\end{array}$ & Nova Scotia & 189.5 & 123.7 & 99.57 & 94.6 & 79 & -20.4 & 181.5 & 124.7 & 98.3 & 97.3 & 76.9 & -1.4 & 32.8 & 112.6 & 4.3 & 1.8 & 2.6 \\
\hline & YPM 519 & $\begin{array}{l}\text { Howard } \\
\text { Limestone }\end{array}$ & Gzhelian & Kansas & 315.3 & 193.1 & 107.9 & 156.4 & 113.1 & -7.3 & 314.6 & 190.1 & 108.3 & 152.7 & 112.4 & 4.3 & 46.3 & 216.7 & 4.2 & 1.5 & 2.9 \\
\hline \multirow[t]{2}{*}{$\begin{array}{l}\text { Varanopus } \\
\text { microdactylus }\end{array}$} & $\begin{array}{l}\text { NSM } 997 \text { GF } \\
30.6\end{array}$ & Cape John & $\begin{array}{l}\text { Gzhelian- } \\
\text { Asselian }\end{array}$ & Nova Scotia & 106.7 & 79.2 & 84 & 52.4 & 59 & 4.3 & 97.3 & 80.5 & 74.3 & 48.3 & 63.7 & 17.4 & 29.8 & 80.6 & 4.3 & 2.4 & 3.2 \\
\hline & $\begin{array}{l}\text { NSM } 99 \text { GF } \\
34 b\end{array}$ & Cape John & $\begin{array}{l}\text { Gzhelian- } \\
\text { Asselian }\end{array}$ & Nova Scotia & 130.8 & 93.1 & 90.3 & 67.1 & 63.6 & 4 & 133.4 & 86.2 & 102.8 & 67.5 & 50.2 & 5.1 & 37.9 & 109 & 3.6 & 1.8 & 3.0 \\
\hline \multirow[t]{11}{*}{$\begin{array}{l}\text { Notalacerta } \\
\text { missouriensis }\end{array}$} & $\begin{array}{l}\text { NMMNH P } \\
31705\end{array}$ & McAlester & Late Moscovian & Oklahoma & 74.8 & 51.7 & 92.0 & 36.7 & 37.2 & 1.6 & 74.0 & 53.6 & 84.0 & 35.8 & 39.8 & 3.9 & 18.9 & 55.5 & 3.7 & 1.8 & 2.7 \\
\hline & $\begin{array}{l}\text { NMMNH P } \\
31746-7\end{array}$ & McAlester & Late Moscovian & Oklahoma & 69.2 & 42.5 & 107.8 & 34.3 & 24.8 & 7.8 & 74.0 & 46.3 & 104.3 & 36.5 & 28.2 & 11.1 & 20.2 & 56.6 & 3.9 & 1.4 & 3.2 \\
\hline & $\begin{array}{l}\text { NMMNH P } \\
31749\end{array}$ & McAlester & Late Moscovian & Oklahoma & 63.4 & 47.3 & 92.6 & 33.3 & 33.2 & -8.4 & 58.2 & 40.3 & 90.5 & 28.3 & 28.6 & 4.3 & 17.0 & 50.7 & 3.5 & 1.9 & 2.8 \\
\hline & $\begin{array}{l}\text { NMMNH } \\
\text { P-31751 }\end{array}$ & McAlester & Late Moscovian & Oklahoma & 63.9 & 41.0 & 102.2 & 31.8 & 25.8 & -0.7 & 64.0 & 41.6 & 96.8 & 30.9 & 27.8 & 6.4 & 16.3 & 48.0 & 4.3 & 1.7 & 3.2 \\
\hline & $\begin{array}{l}\text { NMMNH } \\
\text { P-31759-61 }\end{array}$ & McAlester & Late Moscovian & Oklahoma & 67.1 & 43.2 & 102.6 & 33.7 & 26.8 & 4.2 & 66.1 & 44.3 & 98.1 & 33.7 & 28.7 & 8.0 & 23.4 & 56.7 & 4.1 & 1.7 & 3.5 \\
\hline & $\begin{array}{l}\text { NSM } \\
\text { 008GF031.068 }\end{array}$ & Joggins & Late Bashkirian & Nova Scotia & 75.8 & 66.9 & 70.7 & 41 & 51.8 & -13.2 & 85.8 & 58 & 97.8 & 44.2 & 37 & 11.7 & 28.8 & 71.5 & 2.5 & 1.7 & 2.4 \\
\hline & KGS 1381 & Lee & Late Bashkirian & Kentucky & 102.4 & 90.1 & 69 & 51.2 & 73.2 & -18.8 & 100.2 & 68.9 & 93.2 & 49.5 & 47.4 & -0.4 & 24.8 & 74.9 & 2.7 & 1.9 & 2.0 \\
\hline & UGKU 1914 & Pottsville & Late Bashkirian & Alabama & 62.9 & 50 & 78.1 & 32.3 & 37.4 & -44.1 & 61.5 & 44.2 & 88.9 & 31.7 & 29.8 & -2.7 & 14.2 & 49.4 & 3.3 & 2.0 & 2.6 \\
\hline & JL-NN 1 & 1 Pottsville & Late Bashkirian & Alabama & 66.4 & 52.4 & 77.9 & 31.4 & 40.9 & -10.5 & 66 & 43.4 & 100.8 & 32.3 & 28 & 17 & 14.2 & 44.1 & 3.3 & 2.1 & 2.2 \\
\hline & & 2 & & & 58.1 & 48.2 & 76.6 & 30.2 & 37.8 & -18.8 & 63.4 & 42.2 & 98.2 & 31.4 & 27.6 & 10.2 & 14.2 & 43.3 & 2.7 & 1.8 & 2.0 \\
\hline & & 3 & & & 53.2 & 43.4 & 79.2 & 32 & 25.9 & -8.3 & 45.8 & 33.5 & 93.8 & 27.5 & 17.4 & 23 & 14 & 39.7 & 2.5 & 1.2 & 1.9 \\
\hline \multirow[t]{11}{*}{$\begin{array}{l}\text { Hylopus } \\
\text { hardingi }\end{array}$} & SGM SA & Sulzbach & $\begin{array}{l}\text { Early } \\
\text { Moscovian }\end{array}$ & Germany & 374.8 & 206 & 130.9 & 187.4 & 85.7 & 9.4 & 331.7 & 207.5 & 102.5 & 159.7 & 130.8 & -18.7 & 145.5 & 342.4 & 3.5 & 0.8 & 3.2 \\
\hline & $\begin{array}{l}\text { NSM } \\
\text { 008GF031.068 }\end{array}$ & Joggins & Late Bashkirian & Nova Scotia & 75.8 & 66.9 & 70.7 & 41 & 51.8 & -13.2 & 85.8 & 58 & 97.8 & 44.2 & 37 & 11.7 & 28.8 & 71.5 & 2.5 & 1.7 & 2.4 \\
\hline & $\begin{array}{l}\text { NSM } \\
\text { 008GF039.039 }\end{array}$ & Joggins & Late Bashkirian & Nova Scotia & 146.5 & 125.9 & 70.7 & 73.2 & 102.3 & -39.1 & 132.8 & 103.3 & 80.1 & 66.7 & 79.4 & -19.4 & 48.5 & 117.3 & 3.0 & 2.1 & 2.4 \\
\hline & $\begin{array}{l}\text { NSM } \\
\text { 008GF039.336 }\end{array}$ & Joggins & Late Bashkirian & Nova Scotia & & & & & & & 96.9 & 67.2 & 92.1 & 48.4 & 46.7 & 15.3 & 17.8 & & & & \\
\hline & $\begin{array}{l}\text { NSM } \\
\text { 010GF045.051 }\end{array}$ & Joggins & Late Bashkirian & Nova Scotia & 149.2 & 122.3 & 74.7 & 73.2 & 97.5 & -7.8 & 152.1 & 92.8 & 110.6 & 76.6 & 51.9 & 23 & 50.5 & 129.8 & 3.7 & 2.4 & 3.2 \\
\hline & NBMG 14143 & Grande Anse & Late Bashkirian & New Brunswick & 168.1 & 154.1 & 66.2 & 85.1 & 127.8 & -32.2 & 174.7 & 140.4 & 76.6 & 87 & 109.5 & -13.7 & 71.1 & 159.1 & 2.9 & 2.2 & 2.7 \\
\hline & UCM 263 JT & Pottsville & Late Bashkirian & Alabama & 149.3 & 103 & 93 & 74.7 & 70.7 & & 131.8 & 85.5 & 114.5 & 71.9 & 46.1 & 14.3 & 43.2 & 118.9 & & & \\
\hline & NBMG 3060 & Parrsboro & early Bashkirian & Nova Scotia & 140.1 & 89 & 106 & 71.9 & 51.8 & 1.3 & 142 & 94.3 & 100.2 & 74.3 & 57.5 & 10.5 & 26.8 & 101.7 & 3.6 & 1.3 & 2.6 \\
\hline & MCZ 267 & West Bay & $\begin{array}{l}\text { Late } \\
\text { Mississippian }\end{array}$ & Nova Scotia & & 205.1 & & 187.3 & 82.3 & -15.8 & & 232.2 & & 193.7 & 128 & 2 & 37.9 & & & 0.8 & \\
\hline & YPM-PU 18828 & Pomquet & $\begin{array}{l}\text { Late } \\
\text { Mississippian }\end{array}$ & Nova Scotia & 192.2 & 111.8 & 118.5 & 95.9 & 56.6 & -10 & 183.2 & 108.2 & 115.6 & 91.7 & 56.8 & 11.7 & 16.3 & 106.3 & 4.3 & 1.3 & 2.4 \\
\hline & NBMG 10128 & Enrage & $\begin{array}{l}\text { Late } \\
\text { Mississippian }\end{array}$ & New Brunswick & 127.6 & & & & & & 130.1 & & & & & 1.7 & 37.1 & & & & \\
\hline
\end{tabular}




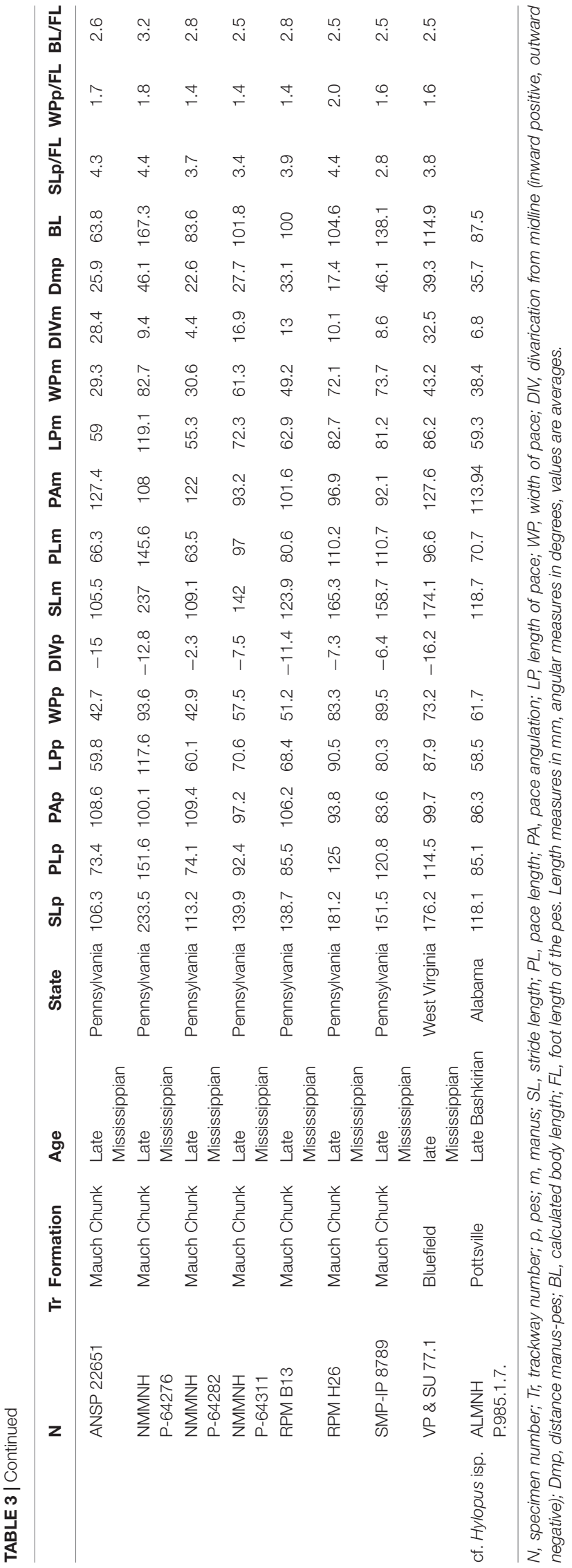

orientation of the manus with respect to the pes-were chosen for multivariate comparison and statistical testing. These six parameters can describe a symmetrical homogeneous trackway pattern exhaustively, minimize redundancy and can also be interpreted in terms of trackmaker function (e.g., Buchwitz and Voigt, 2018).

We employ standard multivariate normality tests implemented in PAST3 (Mardia tests, Doornik and Hansen omnibus) to find out whether empirical distributions follow a multivariate normal distribution. Depending on the test results, we continued either with multivariate analysis of variance (MANOVA) - to test the overall distinctiveness of the predefined groups via two different test statistics (Wilk's lambda, Pillai trace) and to determine the degree of distinction between pairs of groups (Mahalanobis distances)-or permutational analysis of variance (PERMANOVA) as a non-parametric alternative test.

In the next analysis step, we used linear discriminant analysis (LDA) to address the question of how well the four groups can be separated from each other through linear discriminant functions. In the analysis of Hylopus and Notalacerta samples, five Pennsylvanian trackways (Gzhelian Dromopus, Gzhelian Varanopus, Moscovian Hylopus) were included as unassigned specimens in order to determine how they are sorted into one of the four groups. In three further LDAs based on the same set of trackway parameters, the Notalacerta samples were considered alone, in combination with Cisuralian Dromopus and Varanopus samples and in combination with the joint Gzhelian-Cisuralian samples of Dromopus and Varanopus.

\section{Institutional Abbreviations}

ALMNH -Alabama Museum of Natural History, Tuscaloosa, Alabama, United States, ANSP-Academy of Natural Sciences, Philadelphia, Pennsylvania, United States, BIRUG-University of Birmingham's Lapworth, Birmingham, Museum of Geology, United Kingdom, CMN-Canadian Museum of Nature, Ottawa, Canada, DBM-Deutsches Bergbau-Museum, Bochum, Germany, JL-Private collection of Jim Lacefield, Tuscumbia, Alabama, United States, KGS-Paleontological Collections of the Kentucky Geological Survey, Kentucky, United States, KUBiodiversity Institute and Natural History Museum, Lawrence, Kansas, United States, MCZ-Museum of Comparative Zoology, Harvard University, Cambridge, Massachusetts, United States, MNG-Museum der Natur, Stiftung Schloss Friedenstein, Gotha, Germany, NBMG-New Brunswick Museum, Saint John, Canada, NMMNH-New Mexico Museum of Natural History, Albuquerque, New Mexico, NSM-Nova Scotia Museum, Halifax, Canada, ROM-Royal Ontario Museum, Toronto, Canada, RPM-Reading Public Museum, Reading, Pennsylvania, United States, SGM-Geologisches Museum der Saarbergwerke AG, Saarbrücken, Germany, SMP—State Museum of Pennsylvania, Harrisburg, Pennsylvania, United States, UCM-Anniston Museum of Natural History, Anniston, Alabama, United States, UGKU-Urweltmuseum GEOSKOP, Thallichtenberg, Germany, USNM-National Museum of Natural History, Smithsonian Institution, Washington, D.C., United States, VP \& SU-Department of Geological Sciences, Virginia Polytechnic Institute and State University, Blacksburg, 
Virginia, United States, YPM-Yale Peabody Museum, New Haven, Connecticut, United States.

\section{RESULTS}

\section{Tracks Attributed to Anamniote Reptiliomorph Tracks}

\author{
Hylopus (Dawson, 1882) (Figures 1D, 2D, and 3-5).
}

\section{Type and Included Ichnospecies}

Type and only ichnospecies Hylopus hardingi (= H. hamesi). $H$. caudifer and $H$. logani are here regarded as nomina dubia.

\section{Revised Diagnosis}

Five distinct digits on manus and pes, relatively long and slender (different from the temnospondyl tracks Batrachichnus, Limnopus, and Matthewichnus, which have a tetradactyl manus). Pedal footprints 25-107 $\mathrm{mm}$ long (51 $\mathrm{mm}$ on average), manual tracks about $1 / 3$ shorter. Digits I-IV significantly increasing in length in the manus, more than in the pes (different from the amniote tracks Notalacerta and Varanopus and the anamniote tracks Amphisauropus and Ichniotherium, in which digits I-IV increase in length more markedly in the pes). Digit $\mathrm{V}$ as long as digit II (manus) or slightly shorter than III (pes) (different from Dromopus, in which digit $\mathrm{V}$ has a similar relative length in the pes and manus). Larger divergence between manus digits III-IV than between manus digits I-II and II-III (different from Notalacerta, which has a smaller manus digit III-IV divergence). Similar total divarication in pes and manus (different from Notalacerta and Dimetropus, which have a larger total divarication in the manus compared to the pes). Digit bases diverging and not laterally overlapping (different from Dromopus and Varanopus, which show proximal-lateral overlap of digit bases). Digit terminations tapering or enlarged, rarely with pointed end (different from amniote tracks, which show sharp terminations and claw marks). Digits distally markedly curved inwards (different from most anamniote tracks, which show straight digits). In fully impressed tracks, distinct, small circular basal pad of digit I in both pes and manus (different from all the amniote tracks and Ichniotherium cottae and I. sphaerodactylum, which do not have this feature). Semiplantigrade manus and semiplantigrade to plantigrade pes (different from Dromopus, which is semidigitigrade, and Dimetropus, which has a plantigrade pes). Both manus and pes slightly wider than long (different from Notalacerta and Dimetropus, in which the manus is slightly wider than long and the pes longer than wide, respectively). Palm relatively short, sole relatively short to proximally elongated with concave (manus and pes) or convex (pes) proximal margin, usually not impressed (the proximal elongation is not observed in Notalacerta). Simple alternating arrangement of close pes-manus couples, sometimes showing partial pes-manus overstep. Broad to relatively narrow trackways, pace angulation moderately high, ranging between 66 and $131^{\circ}$, being $100^{\circ}$ on average and generally higher in manus imprints (different from Notalacerta and Dimetropus, which have a lower manus pace angulation). Relatively rare body/tail drag mark (different from Amphisauropus and Notalacerta).
Pes outward-directed and manus forward- to slightly inward-directed.

$$
\text { Hylopus hardingi (Dawson, 1882). }
$$

1863 Footprints of reptiles-Dawson, p. 6, pl. I, Figure 2 1882 Hylopus hardingi n. igen. n. isp.-Dawson, p. 653 1933 Hylopus hardingi-Sternberg, p. 952-953, pl. 36, Figure 2 1947 Palaeosauropus isp.-Colbert and Schaeffer, p. 614-618, pl. 1

1956 Asperipes isp.-Schmidt, p. 204-205, Figure 3

1982 Cincosaurus tauentzieni n. isp.-Fichter, p. 38-45, Figures 2-3 and Tables 1,2

1990 Hylopus hamesi n. isp.-Sundberg et al., p. 115, Figures 4, 5 and Tables 1-3

2000 Hylopus hardingi-Mossman and Grantham, p. 194-195, Figure 8 and Table 2

2005 Cincosaurus cobbi-Haubold et al., p. 96, 109, Figure 8B 2007 aff. Pseudobradypus longidigitatus-Falcon-Lang et al., p. 1114-1115, Figure 3 and Table 1

2007 Hylopus hardingi-Vrazo et al., p. 200-201, Figures 1, 2 and Tables 1-3

2007 Pseudobradypus isp.-Wood and Miller, p. 183-185, Figures 3, 4 and Table 1

2008 Amphisauroides isp.-Turek et al., p. 48-49, Figure 1B 2010 Pseudobradypus longidigitatus-Falcon-Lang et al., p. 67, Figures 7-10

2012 Hylopus hardingi-Fillmore et al., p. 58, Figures 47-59

2012 Palaeosauropus primaevus-Fillmore et al., Figure 68B

2012 Pseudobradypus isp.-Fillmore et al., Figure 74A

2020a Notalacerta missouriensis-Marchetti et al., Figure 7J

\section{Diagnosis}

Same as for the ichnogenus.

\section{Remarks}

Hylopus hardingi is morphologically similar to Carboniferous ichnotaxa attributed to anamniote reptiliomorphs and reptiles (Figures 1, 2). It differs from the reptile track Notalacerta missouriensis based on the more ectaxonic and narrower manus with higher digit III-IV divergence and less ectaxonic and wider pes, as well as the broader palm/sole impression and the occurrence of circular basal pads of digit I. It differs from the reptile tracks Varanopus microdactylus and Dromopus lacertoides in the markedly lower pedal ectaxony, the non-occurrence of digit-base lateral overlap, the absence of sharp claw marks, the less curved pes digit I-IV imprints, the broader palm/sole impression and the occurrence of circular basal pads of digit I. It differs from the seymouriamorph track Amphisauropus kablikae in the narrower and more ectaxonic manus imprint, with a higher digit III-IV divergence and a relatively shorter digit $\mathrm{V}$ in the manus relative to digit IV. It differs from the diadectomorph track Ichniotherium cottae as a result of the more ectaxonic manus imprint and less ectaxonic pes imprint, the higher digit III-IV divergence and a relatively shorter digit $\mathrm{V}$ relative to digit IV in the manus, the shorter and non-elliptical palm/sole impression, and the occurrence of digit I basal pads. 
The ichnogenus Hylopus was introduced by Dawson (1882) with the ichnospecies $H$. caudifer, $H$. hardingi and $H$. logani. Since the type ichnospecies was not specified, Matthew (1904) chose $H$. hardingi as the type ichnospecies of the ichnogenus. We follow this interpretation, because it is in agreement with the ICZN (1999). H. hardingi was erected on the base of a "plastotype" (Dawson, 1863, pl. I, Figure 2; NBMG 3060, Figure 3) of a specimen coming from the Parrsboro Formation of Nova Scotia, showing a trackway including five consecutive pes-manus couples. The original specimen was last reported to be in the King's College of Windsor, Nova Scotia (Dawson, 1863, p. 6) and subsequently lost in a fire (Fedak, 2021). An additional cast of the original specimen is stored in the NSM collection. The footprints are relatively well preserved, semiplantigrade and pentadactyl, and the digit imprint proportions and arrangement are diagnostic. Digit I imprints are relatively shallow, but clearly preserved (Figures 3C-F), whereas digits II-V are more deeply impressed. So, the pentadactyly of this ichnotaxon is definitely confirmed as initially proposed by Dawson (1882). The possible manual tetradactyly suggested by later studies (Matthew, 1904; Sundberg et al., 1990; Fillmore et al., 2012) is rejected here as extramorphological, as is confirmed by additional material preserving five clear manual digit imprints (Figures 4A,E-J, 5A-C). Hylopus hardingi manus imprints that preserve only four digits thus are incomplete pentadactyl tracks: when digit $\mathrm{V}$ is missing, digit IV would be relatively too long to be the most lateral, and when digit $\mathrm{I}$ is missing, digit $\mathrm{V}$ is relatively too short compared to IV to be interpreted as digit IV. Small circular basal pad impressions below digit I are also visible (Figures 3C,D for the manus, Figures 3E,F for the pes). Another trackway from the Parrsboro Formation has been described by Mossman and Grantham (2000, Figure 8). Some undescribed material from the West Bay Formation of Nova Scotia includes incomplete step cycles with well-preserved footprints assignable to Hylopus hardingi (MCZ 267, YPM-PU 16983, YPM-PU 20103). MCZ 267 shows large tracks with unusually large sole impressions in a proximal-lateral position (Figure 4A). An undescribed specimen from the Pomquet Formation of Nova Scotia preserves a trackway showing partial overstep of the pes on the manus. Because of a well-preserved pes-manus couple, it is assignable to Hylopus hardingi (YPM-PU 18828). Sternberg (1933, pl. 36, Figure 2) described a trackway of Hylopus hardingi from the Joggins Formation, Nova Scotia. This is a relatively common ichnotaxon from this unit, several specimens including trackways, incomplete step cycles and isolated pesmanus couples display its diagnostic features, including the basal pad I impression and the typical manus morphology, more ectaxonic than the pes and high digit III-IV divergence (NSM 008GF031.142, NSM 008GF031.352, NSM 008GF039.014, NSM 008GF039.039, NSM 010GF045.051, NSM 294, NSM 300, Figure 4B). These features are also visible on specimens with smaller footprints and thinner digit imprints, such as NSM 008GF039.336 (Figure 4C), initially assigned to Notalacerta missouriensis by Marchetti et al. (2020a). We now assign all of this material to Hylopus hardingi.

A specimen with tracks belonging to two trackways from the Enrage Formation of New Brunswick has been assigned to "Pseudobradypus" isp. and attributed to reptiles (Wood and Miller, 2007). This material clearly displays the diagnostic features of Hylopus hardingi, showing a markedly ectaxonic manus, with high digit III-IV divergence and the impression of the basal pad of digit I (NBMG 10128-1, Figure 4D). We re-assign this material to Hylopus hardingi. A specimen including two trackways from the Grande Anse Formation of New Brunswick (NBMG 14143, Figure 4E) has been compared to "Pseudobradypus," in particular " $P$. longidigitatus," and attributed to reptiles by Falcon-Lang et al. (2007). This attribution has been questioned by several subsequent studies (e.g., Keighley et al., 2008; Fillmore et al., 2012; Lucas, 2019; Marchetti et al., 2019a). The latter re-assigned this material to Hylopus isp. The narrow manus, more ectaxonic than the pes with a basal pad impression of digit I, is diagnostic, so we re-assign this material to Hylopus hardingi. Some material from the Tynemouth Creek Formation of New Brunswick has been assigned to "Pseudobradypus longidigitatus" and attributed to reptiles by Falcon-Lang et al. (2010). Aside from the relatively poor overall preservation, a few pes-manus couples show the typical morphology of Hylopus hardingi, with a semiplantigrade and weakly ectaxonic pes (e.g., Falcon-Lang et al., 2010, Figures 8, 10). So, we reject the assignment to " $P$. longidigitatus" and assign this material to Hylopus hardingi.

The ichnospecies Hylopus "hamesi” Sundberg et al., 1990 from the Bluefield Formation of West Virginia has been interpreted as having pes digit imprints of subequal length. This, together with the proximal-lateral extension of the sole impression and the thinner manus digit imprints, was used to distinguish Hylopus "hamesi" from Hylopus hardingi. Nevertheless, the subequal lengths of pes digit imprints are only apparent and caused by the outward rotation of the pes, as is clear from the better-preserved pes of the paratype material (Sundberg et al., 1990, Figure 5A). The other features are not diagnostic and/or can be present in Hylopus hardingi. Accordingly, we consider H. "hamesi" a junior subjective synonym of $H$. hardingi, in agreement with Fillmore et al. (2012). Some material from the Pottsville Formation of Alabama (e.g., Haubold et al., 2005), previously assigned to "Cincosaurus cobbi," shows the typical morphology of the manus imprint of $H$. hardingi: narrow, markedly ectaxonic and with higher divergence between digits III-IV (e.g., UCM 263 JT, Figure 4F). We assign this material to $H$. hardingi. The Mauch Chunk Formation of Pennsylvania yields the most abundant, well preserved and complete record of Hylopus hardingi worldwide, encompassing numerous trackways (Vrazo et al., 2007; Fillmore et al., 2012; Figures 1D, 4G-J, 5A-C). Especially relevant are trackways showing transitional morphology on the same side (SMP-IP 8789, Figure 4G) or on different sides (NMMNH P64276, Figure 5A). This is revealing of the mechanism of the formation of typical extramorphologies such as: the preservation of only the digit I-III imprints in the pes, which can be dragged forward, the result of a lateral orientation of the pes, or the nonpreservation of the basal pad of digit I, which happens when the proximal part of digit I is not impressed. Some specimens show relatively small footprints with thin digit imprints, with the typical manus digit III-IV divergence, ectaxony or digit I basal pad impression of $H$. hardingi (NMMNH P-64282, 
NMMNH P-64311, SMP-VP 2325, Figure 4H). Some specimens may show pointed digit terminations, laterally elongated sole impressions or continuous, thin and straight tail impressions (NMMNH P-64275, RPM B13, RPM H26). Two specimens previously assigned to Palaeosauropus primevus (NMMNH P64275) and Pseudobradypus isp. (RPM B13) (Fillmore et al., 2012, Figures 68B, 74A) show typical features of Hylopus hardingi such as the marked manual ectaxony with high digit III-IV divergence and pentadactyly. We re-assign these specimens to Hylopus hardingi. The holotype of Palaeosauropus primaevus Lea, 1849 (ANSP 9752) is a pes-manus couple with an incompletely impressed manus imprint (Lucas et al., 2010, Figure 2; Fillmore et al., 2012, Figures 6A,B). The manus shows four digit imprints, which have similar morphology and proportions compared to digit II-V imprints of $H$. hardingi. Also, the morphology and trackway pattern of another specimen originally assigned to this ichnotaxon (Lucas et al., 2010, Figure 3; Fillmore et al., 2012, Figures 6C,D) with relatively high pace, primary pesmanus overstep and laterally elongated sole, is consistent with $H$. hardingi. Further studies are necessary to verify the validity of this ichnotaxon and possible synonymies with $H$. hardingi. An incomplete step cycle from the Upper Mississippian Tar Springs Formation of Indiana, assigned to Palaeosauropus isp. (Colbert and Schaeffer, 1947, pl. 1) shows the typical morphology and proportions of the pes and manus of Hylopus hardingi, including a manus more ectaxonic than the pes and a circular basal pad of digit I. The manus preserves only four digit imprints, but their proportions are identical to the digit II-V proportions of $H$. hardingi, so we re-assign this material to H. hardingi.

Material previously classified as "Asperipes" isp. by Schmidt (1956) from the Bochum Formation of Germany is here reassigned to Hylopus hardingi because of the good preservation of the pes imprint (DBM-NN 1, Figure 4K), showing the typical weak ectaxony, semiplantigrady and digit $\mathrm{V}$ relative length and orientation. The study of a trackway from the Sulzbach Formation of Germany (SGM SA), permits the attribution of "Cincosaurus tauentzieni" Fichter, 1982 to H. hardingi, because of the typical manual morphology with diverging digit III-IV imprints. A single trackway with two incomplete manus-pes couples from the Žaclér Formation of the Intrasudetic Basin in the Czech Republic, previously assigned to Amphisauroides Haubold, 1970 (Turek et al., 2008, Figure 1B), is herein reassigned to Hylopus hardingi because of the imprint morphology, especially the manual digit proportions with marked ectaxony and short palm impression with a concave proximal margin.

Some material, which is morphologically similar to Hylopus hardingi, but too poorly preserved for a definitive assignment, is herein discussed. The holotype of Hylopus "logani" Dawson, 1882 from the Horton Bluff Formation of Blue Beach, Nova Scotia (CMN 4622) shows a trackway with digit drag marks, which has no diagnostic features. We consider Hylopus "logani" as a nomen dubium and assign this material as undetermined tetrapod footprints. Some of the material from the same unit such as the holotypes of "Anticheiropus bishopi" Sarjeant and Mossman, 1978 and "Eochelysipus horni" Mossman and Grantham, 2008 show some similarities with Hylopus hardingi, but due to their poor preservation (especially the manual tracks), we considered these ichnotaxa as nomina dubia. This material, and the material assigned to Hylopus by Mansky and Lucas (2013) are reassigned to cf. Hylopus isp. The trackways of morphotype D described by Keighley and Pickerill (1998, Figures 8, 9) from the Port Hood Formation of Nova Scotia, partly assigned to cf. Notalacerta isp. by Marchetti et al. (2020a), are assignable to cf. Hylopus isp., mostly because of the manus morphology, which is more ectaxonic, narrower and with a more concave palm proximal margin than Notalacerta. We consider Hylopus "caudifer" Dawson, 1882 from the Joggins Formation of Nova Scotia (Dawson, 1863, pl. I, Figure 3) as a nomen dubium, because of its overall incompleteness and poor preservation. This trackway is tentatively assigned to cf. Batrachichnus isp.

A trackway from the Boss Point Formation of Oxford Junction, Nova Scotia, is the holotype of "Laoporus canadensis" Sternberg, 1933 (CMN 4631). Because of the poor preservation of the holotype trackway, especially of the manus imprints, we consider this ichnotaxon as a nomen dubium. Nevertheless, the most recognizable pes imprints are weakly ectaxonic and semiplantigrade, in agreement with Hylopus hardingi. We tentatively assign this specimen to cf. Hylopus isp. This locality, also known as River Philip (e.g., Cotton et al., 1995), was first reported by Selwyn (1872), who specified that it was situated about $3 / 4$ of mile $(1.2 \mathrm{~km})$ east of the railroad bridge on River Philip, Nova Scotia. The bridge is in Oxford Junction, and according to the most recent geologic mapping, the track-bearing outcrop is in the Boss Point Formation (Ryan et al., 1991). This locality yielded also the holotype and paratype trackways of "Pseudobradypus unguifer" (Dawson, 1882) and "Pseudobradypus" Matthew, 1903 (CMN 4630 and CMN 4629, respectively) and the holotype trackway of “Asperipes longidigitatus" Sternberg, 1933, renamed "Pseudobradypus longidigitatus" by Haubold (1971) (CMN 4629). This material is poorly preserved so it is difficult to interpret it. Marchetti et al. (2019a) considered Pseudobradypus unguifer as a nomen dubium because of the poor preservation of the manus imprints and re-assigned the type material to cf. Dimetropus isp., because of the morphological similarity of the pes imprints with Dimetropus material from the Tambach Formation (e.g., Voigt, 2005), and we agree with this assignment. Because of the poor preservation of the pes imprints, we consider "Asperipes longidigitatus" as a nomen dubium. Nevertheless, the manus morphology and proportions with bifurcated digit tips are generally consistent with Dimetropus, so we re-assign this material to cf. Dimetropus isp. The re-assignment of this material is key in Carboniferous ichnotaxonomy, because several times "Pseudobradypus" has been inappropriately used to classify Hylopus tracks and/or to claim an attribution to reptile producers (e.g., Falcon-Lang et al., 2007, 2010; Wood and Miller, 2007; Fillmore et al., 2012; Niedźwiedzki, 2015).

A manus imprint from the Rhode Island Formation of Massachusetts, initially assigned to Notalacerta (Fichman et al., 2015), has been re-assigned to cf. Hylopus isp. by Marchetti et al. (2020a) because of the presence of a basal pad of digit I. The ichnotaxon "Quadropedia prima" in Aldrich and Jones (1930) from the Pottsville Formation of Alabama (e.g., Haubold et al., 2005) includes a trackway with very incomplete pes imprints. We consider this ichnotaxon as a nomen dubium. Nevertheless, the manus morphology is similar to $H$. hardingi, so we assign this 
material to cf. Hylopus isp. Unfortunately, although abundant, most of the morphologically-similar material from this site lacks completely impressed tracks (especially regarding the pes), so it is not unequivocally assignable to Hylopus hardingi because of its similarities with other ichnotaxa such as Notalacerta missouriensis. Possibly, this could be clarified by a comprehensive anatomy-consistent ichnotaxonomic revision of the Pottsville Formation tracks, together with the analysis of track and trackway parameters of this material. Two trackways from the late Moscovian Llewellyn Formation of Pennsylvania were assigned to cf. Hylopus hardingi by Fillmore et al. (2015, Figure 5). However, the smaller manus imprints, which appear tetradactyl on ANSP V 7264 and pentadactyl on ANSP V 7266 are too poorly preserved for a definitive assignment. Nonetheless, they both differ from the typical morphology of Hylopus hardingi because the digits are shorter and the footprints wider and less ectaxonic.

Lagnaoui et al. (2014) assigned isolated tracks from the Galmous Formation of Morocco to cf. Hylopus isp.; we agree with this assignment. A few isolated tracks assigned to aff. "Pseudobradypus" from the Lublin Formation of Poland (Niedźwiedzki, 2015; Figures 3D-F), are herein re-assigned to cf. Hylopus isp. because of the higher ectaxony of the manus imprints compared to the pes and the curved manus digit imprints. Mietto et al. (1986) assigned an isolated and incomplete manus from the Gzhelian Corona Formation of Italy to Hylopus cf. hardingi. This material has been re-assigned to Limnopus isp. (see Marchetti et al., 2020c).

\section{Trackmaker Attribution}

Since its introduction, the ichnotaxon Hylopus hardingi was generally attributed to anamniote producers (Dawson, 1863) because of the broad and well-divaricated digits with rounded terminations, and the supposed occurrence of tetradactyl manus tracks (here interpreted as missing the impression of digit $\mathrm{I}$ or $\mathrm{V}$ ), and this attribution was generally accepted by subsequent authors (e.g., Haubold, 1971; Sundberg et al., 1990; Cotton et al., 1995; Fillmore et al., 2012; Lucas, 2019; Marchetti et al., 2019a, 2020a). The presence of five digits in the manus of well-preserved specimens, here definitively confirmed, suggests a possible anamniote reptiliomorph producer rather than temnospondyls or lepospondyls, which had instead a tetradactyl manus (e.g., Dilkes, 2014; Glienke, 2015). Among anamniote reptiliomorphs, seymouriamorphs have a non-overlapping stratigraphic range with $H$. hardingi. The seymouriamorphs probably appeared in the Gzhelian (Klembara and Ruta, 2003), whereas $H$. hardingi has an older, Mississippian-Moscovian stratigraphic range. Moreover, the manus proportions of seymouriamorphs are different, being much wider and less ectaxonic than $H$. hardingi (such as Seymouria sanjuanensis described from the Bromacker site of Germany by Berman et al., 2000). Based on this material, seymouriamorphs have been correlated to the ichnotaxon Amphisauropus kablikae, based on a morphofunctional comparison (Marchetti et al., 2017). So, we can exclude seymouriamorphs as possible producers of $H$. hardingi.

Diadectomorphs also have a different stratigraphic range (Kasimovian-Cisuralian: Kissel and Lehman, 2002; Lucas, 2018), although tracks attributed to diadectomorphs include older records (Bashkirian-Moscovian, Haubold and Sarjeant, 1973; Voigt and Ganzelewski, 2010). Also, diadectomorphs gemerally have a larger size range than Hylopus hardingi, show a less ectaxonic manus and more ectaxonic pes and have a very broad and elliptical tarsal structure, which is not in agreement with $H$. hardingi. The diadectomorphs Orobates pabsti, Diadectes absitus, and Limnoscelis paludis have been instead correlated to the ichnogenus Ichniotherium through morphofunctional comparisons (Voigt et al., 2007; Mujal and Marchetti, 2020). So, we can exclude diadectomorphs as possible producers of $H$. hardingi.

We compared the best-preserved pes-manus couples and the trackway pattern of Hylopus hardingi (Figures 5A-C) to the most complete appendicular skeleton of anamniote reptiliomorphs in the Carboniferous, that of Proterogyrinus scheelei (already signaled as a possible producer by Sundberg et al., 1990; Figure 5D). The digit proportions of the manus and pes, as reconstructed by Holmes (1984), are generally consistent with $H$. hardingi. They are in fact both ectaxonic (more so in the manus), and the digit $\mathrm{V}$ of the manus is short and slender, like digit II, whereas the digit $\mathrm{V}$ of the pes is thicker and longer, like digit III. The tarsus is broad, but probably capable of substantial flexion in the medial part. Since the tibiale was a continuation of the tibia, most of the flexion occurred in the centralia, which are wedge-shaped. This is in agreement with the medial semiplantigrady and occasional impression of a laterally expanded sole of $H$. hardingi. Most of the weight was supported by the three centralia, compressed by the intermedium bearing half the weight of the fibula, and the tibiale bearing the entire weight of the tibia. This is in agreement with the deeper impression of pedal digits I-III and the occurrence of a circular fleshy pad corresponding to centrale 1 (Figure 6C), which was probably the most stressed point in the tarsus (as in Seymouria-Amphisauropus: Marchetti et al., 2017). Although lacking the tarsus, morphologically analogous pedes are observed in Greererpeton burkemorani, Pederpes finneyae, and Silvanerpeton miripedes (e.g., Clack, 2002; Figure 5F). A similar manus structure is observed in Casineria kiddi (e.g., Paton et al., 1999; Figure 5E). The manus of Gephyrostegus appears less ectaxonic than Hylopus hardingi. Unfortunately, articulated and complete carpal structures are not known from Carboniferous non-diadectomorph anamniote reptiliomorphs. The measured apparent trunk length is generally shorter in Hylopus hardingi than those expected from forms with long vertebral column compared to the limb length, such as embolomeres and some basal tetrapodomorphs. This should be investigated by future approaches.

\section{Tracks Attributed to Basal Reptiles}

Notalacerta missouriensis (Butts, 1891) (Figures 1A, 2A, and 6).

\section{Description}

Each footprint has five slender digits, and each digit tapers from the base to the extremity. Digit termination acuminate, bifurcated or pointed, evidence of thin sharp claws. Manus slightly wider than long, and pes about as long as wide, pes 
length of $15-38 \mathrm{~mm}$ (22 $\mathrm{mm}$ on average), manus about $1 / 4$ shorter. Marked increase of length between digits I and IV in both pes and manus but more marked in the pes, digit $\mathrm{V}$ as long as digit II (manus) or as long as or slightly shorter than III (pes). No digit superimposition, and digit $\mathrm{V}$ base in line with the bases of digits I-IV. The digits I-IV can be distally curved inward; digits long, compared to size of foot. Variably oriented digit imprints, especially digit III, which can be parallel to digit IV in the manus and to digit II in the pes. High total digit divergence, especially in the manus, commonly higher than $95^{\circ}$. Marked median-lateral decrease in relief in the pes and semiplantigrade footprints. Very short and usually not impressed sole and palm traces. Simple, alternating arrangement of close pes-manus couples, with a moderate pace angulation $\left(70-110^{\circ}\right.$, $91^{\circ}$ on average), pes parallel to the midline or rotated outwards, manus slightly rotated inwards. Common thin, straight and continuous tail drag.

\section{Remarks}

Notalacerta missouriensis was erected by Butts (1891), with a short description and simple outline drawing. However, this author did not designate a holotype, and the original material was never relocated (e.g., Baird, 1982; Chesnut et al., 1994; Marchetti et al., 2020a). The only known specimens coming from the type locality (Cement City Limestone, Chanute Formation of Kansas City, Missouri) and preserving possible Notalacerta missouriensis tracks are: MCZ 204-206, USNM 7321 and FMC P 25486. Another specimen from the same locality was illustrated by Branson and Mehl (1932, pl. 10.3). In the recent comprehensive revision of this ichnotaxon, Marchetti et al. (2020a) established as neotype of Notalacerta missouriensis the specimen USNM 7321, which shows a complete and well-preserved pes-manus couple, and used the additional material from the type locality and the extensive record from other Carboniferous-Permian sites to emend the diagnosis of Notalacerta missouriensis. This is the most abundant and widely distributed Pennsylvanian ichnotaxon attributed to reptiles, with the exception of the Gzhelian, when other reptilian ichnotaxa occur (Marchetti et al., 2019a). The McAlester Formation of Oklahoma includes the most abundant, complete and well-preserved record of Notalacerta missouriensis worldwide, encompassing numerous trackways showing a complete morphological spectrum (Lucas et al., 2004; Marchetti et al., 2020a; Figures 6D,E). Notalacerta missouriensis occurs also in the Pottsville Formation of Alabama (Haubold et al., 2005; Marchetti et al., 2020a) and the Rockcastle Sandstone Member of the Lee Formation, Kentucky (Chesnut et al., 1994; Marchetti et al., 2020a). Other occurrences are reported from the Lancaster Formation of New Brunswick (Marchetti et al., 2020a) and the Joggins Formation of Nova Scotia (Marchetti et al., 2020a). The only African record is from the Galmous Formation of Morocco (Lagnaoui et al., 2014).

Some material is more cautiously assigned to cf. Notalacerta isp. because of overall poorer preservation. This includes material from: the Joggins Formation of Nova Scotia, including the type material of "Asperipes avipes" Matthew, 1903, the Stanton Formation of Kansas (Reisz, 1990; Marchetti et al., 2020a), and the Lower Coal Measures of Indiana, including the holotype of “Collettosaurus indianensis" Cox, 1874.

\section{Trackmaker Attribution}

Butts (1891) named Notalacerta ("lizard mark") because of its supposed lizard producers. The first detailed discussion is from Chesnut et al. (1994), who attributed Notalacerta missouriensis to the basal reptile group of protorothyridids because of relative digit length, digit width, claw marks, gait and tail drag. Subsequent works confirmed this interpretation (Lucas et al., 2004; Haubold et al., 2005; Voigt and Lucas, 2018; Marchetti et al., 2020a), discarding any possible attribution of this ichnotaxon to anamniotes or synapsids, because of the evident differences in the appendicular skeleton structure, encompassing broader tarsus/carpus and thicker digits. Araeoscelid diapsids, bolosaurian parareptiles and varanopid synapsids have an ectaxonic pes and manus, long and slender digits with acuminate terminations and relatively short and flexible tarsus/carpus, features potentially similar to the trackmaker of Notalacerta missouriensis. However, they are all characterized by very close, almost parallel and laterally overlapping metatarsals and metacarpals of digits I-IV (Reisz, 1981; Reisz et al., 1984; Lee, 1997; Berman et al., 2000; Spindler et al., 2019). This is not in agreement with Notalacerta missouriensis, which shows well-separated digit imprints radiating at their base (Marchetti et al., 2020a). This feature is not observed in the articulated metatarsus of the basal reptile Hylonomus lyelli and in the articulated metatarsus and metacarpus of the protorothyridid Paleothyris acadiana (Carroll, 1964, 1969). The protorothyridid Paleothyris acadiana has the most complete, articulated and bestpreserved appendicular skeleton among basal reptiles (Carroll, 1969; Figure 6G). The long and thin digits, the ectaxony of both the pes and the manus, and the relatively longer pes digit $\mathrm{V}$ compared to the manus digit $\mathrm{V}$ are in agreement with Notalacerta missouriensis (Figure 6E). Also, the very short and small tarsus/carpus and the rounded/L-shaped distalia 1 and 5 are in agreement with a short palm/sole impression and the medial/lateral orientation of digit I and V imprints. Furthermore, the lateral centrale appears in continuity with the astragalus, so most of the flexion of the medial tarsus was accommodated in the small area between this element and distal tarsals 1-3. This is in agreement with the deeper impression of the medial part of the sole of Notalacerta missouriensis, whereas the lateral part was usually not impressed (Marchetti et al., 2020a; Figure 6F). The morphology and proportions of the pes and manus of the protorothyridid Anthracodromeus longipes (Carroll and Baird, 1972; Figure 6F) and the pes of the basal reptile Hylonomus lyelli (Carroll, 1964, Figure 8) are also consistent with Notalacerta missouriensis. Permian captorhinomorphs such as Thuringothyris mahlendorffae (Müller et al., 2006) may have been the producer of the Permian Notalacerta (Marchetti et al., 2020a).

\section{Tracks Attributed to Parareptiles}

Varanopus microdactylus (Pabst, 1896) (Figures 1B, 2B, and 7).

\section{Description}

Semiplantigrade, pentadactyl, ectaxonic footprints of a smallsized quadruped (pes length $25-36 \mathrm{~mm}, 31 \mathrm{~mm}$ on average). The manus is about $1 / 4$ shorter than the pes. The pes is about as wide as long, whereas the manus is slightly wider than long. Relatively 
long and slender digit imprints, distally tapering and ending in acute terminations or triangular claw marks, curved toward midline. Digit I-IV imprints are slightly curved toward midline and tightly grouped, often showing lateral superimposition of digit bases. Digit V imprint is straight and directed distallylaterally. It is slightly shorter than digit II in the manus and slightly longer than digit II in the pes. Digit length increases from digit I to IV, and digit IV is the longest in both the pes and the manus. Very short palm/sole impression, with straight to slightly concave proximal margin. Both manus and pes show a medial-lateral decrease in relief, which is more marked in the pes impressions (laterally semidigitigrade). Trackways are relatively broad and show a simple and regular alternating arrangement of pes-manus couples, with a moderate pace angulation (74$103^{\circ}, 88^{\circ}$ on average), and with the pes imprint parallel to the midline and the manus imprint slightly directed medially, the manus in front of the pes and never overstepped by it. A continuous and relatively straight tail impression can sometimes be observed.

\section{Remarks}

"Ichnium" microdactylum was erected by Pabst (1896), based on a trackway from the Cisuralian Tambach Formation, Germany. Subsequently, Müller (1954) proposed the new combination Procolophonichnium microdactylum, due to the similarity of the Tambach material with Procolophonichnium Nopcsa, 1923 from the Lopingian-Early Triassic Balfour Formation of South Africa. Haubold (1971) proposed for the same material the new combination Varanopus microdactylus, because of the similarity with Varanopus Moodie, 1929 from the Cisuralian Choza Formation of Texas. More recent studies based on further material from Europe and North America generally confirmed the latter interpretation (e.g., Haubold and Lucas, 2001, 2003; Voigt, 2005; Voigt and Haubold, 2015; Marchetti, 2016). Nevertheless, the relationship of Varanopus with morphologically-similar ichnogenera such as Procolophonichnium Nopcsa, 1923 and Robledopus Voigt et al., 2013 needs to be re-investigated (Marchetti et al., 2019b).

Varanopus currently includes the ichnospecies V. curvidactylus Moodie, 1929 and V. microdactylus (Pabst, 1896). A straight pes digit $\mathrm{V}$ characterizes both. Nevertheless, $V$. curvidactylus shows a lower pes/manus length ratio and a relatively longer pes digit $\mathrm{V}$, so this ichnospecific differentatiation may be justified. A large quantity of material previously assigned to $V$. curvidactylus or Varanopus isp. needs to be re-analyzed because it is characterized by a relatively short and distally bent pes digit V, a trait shared with Erpetopus Moodie, 1929 from the Cisuralian Choza Formation of Texas (e.g., Haubold and Lucas, 2001, 2003; Gand and Durand, 2006; Marchetti et al., 2015a,b; Voigt and Lucas, 2017). Varanopus is a rare ichnotaxon in the Carboniferous. Van Allen et al. (2005) have assigned well-preserved and relatively long trackways from the GzhelianAsselian Cape John Formation of Nova Scotia to Varanopus cf. microdactylus. Because of the good preservation of the material, we can confirm the assignment to $V$. microdactylus, though these specimens may be of early Permian age. Marchetti et al. (2020d) assigned an incomplete step cycle from the Ghzelian Wescogame
Formation of the Grand Canyon, Arizona, to Varanopus isp. We confirm this assignment.

\section{Trackmaker Attribution}

The ichnogenus Varanopus was initially attributed to Varanosaurus, an ophiacodontid synapsid with markedly ectaxonic autopodia (Moodie, 1929). This interpretation was later discarded in favor of reptilian producers (e.g., Haubold, 1971). Some ophiacodont and sphenacodont taxa such as Ophiacodon and Dimetrodon were characterized by the digital arcade described by Kümmell and Frey (2012), which produces paw-like impressions, not like those observed in Varanopus. Haubold (1971) was the first to propose captorhinomorphs among the possible producers. Fichter (1983) supported an attribution to captorhinomorphs, based on appendicular morphology and proportions of Captorhinus. Voigt (2005) suggested the mesotarsal joint of Captorhinus described by Holmes (2003) as a possible explanation for the medial-lateral decrease in relief of the Varanopus pes. Haubold and Lucas (2001) suggested captorhinomorphs and protorothyridids among the possible producers of Varanopus curvidactylus.

Nevertheless, captohinomorphs, protorothyridids and closely related forms such as Hylonomus are characterized by wellseparated and radiating metatarsals (Carroll, 1964, 1969; Holmes, 2003; Marchetti et al., 2020a), whereas Varanopus tracks show digit impressions that are proximally closely grouped parallel to each other and laterally superimposed (Figure 6B), which is instead the result of the overlap of metatarsals, a feature observed in diapsids, varanopids and parareptiles (e.g., Reisz, 1981; Reisz et al., 1984; Lee, 1997; Berman et al., 2000, 2014; Spindler et al., 2018, 2019). The medial-lateral decrease in relief (medial functional prevalence) of the Varanopus pes imprint (Figure 6C) occurs both in captorhinomorph (Hyloidichnus, Notalacerta) and parareptile footprints (Pachypes, Procolophonichnium nopcsai, P. tirolensis), as evidenced by Mujal et al. (2020). Thus, an attribution of Varanopus to captorhinomorphs, protorothyridids or closely related forms, such as Hylonomus, is presently not well justified. Müller (1954), based on overall morphology and proportions, compared the material from Tambach (V. microdactylus) to Procolophon, and suggested as possible producers Permian parareptiles, such as nycteroleters and nyctiphruretids. Haubold (1971, 1984) proposed parareptiles, such as Nyctiphruretus, as possible producers. Haubold and Lucas (2001) suggested that parareptiles, such as bolosaurians or acleistorhinids, were among the possible producers of Varanopus curvidactylus. Among parareptile groups, only bolosaurians and acleistorhinids are known from Carboniferous units (Modesto et al., 2015; Mann et al., 2019), although well-preserved pes and manus skeletons of the latter are presently unknown.

The only known Carboniferous bolosaurian, Erpetonyx arsenaultorum, has disarticulated but relatively well-preserved pes and manus (Modesto et al., 2015), that allow a reliable reconstruction (Figure 7D). Digit proportions of the pes are generally consistent with Varanopus microdactylus, as is the tarsal structure. The carpus is well preserved and articulated. The small and rounded distal carpal 5 is in agreement with the lateral 


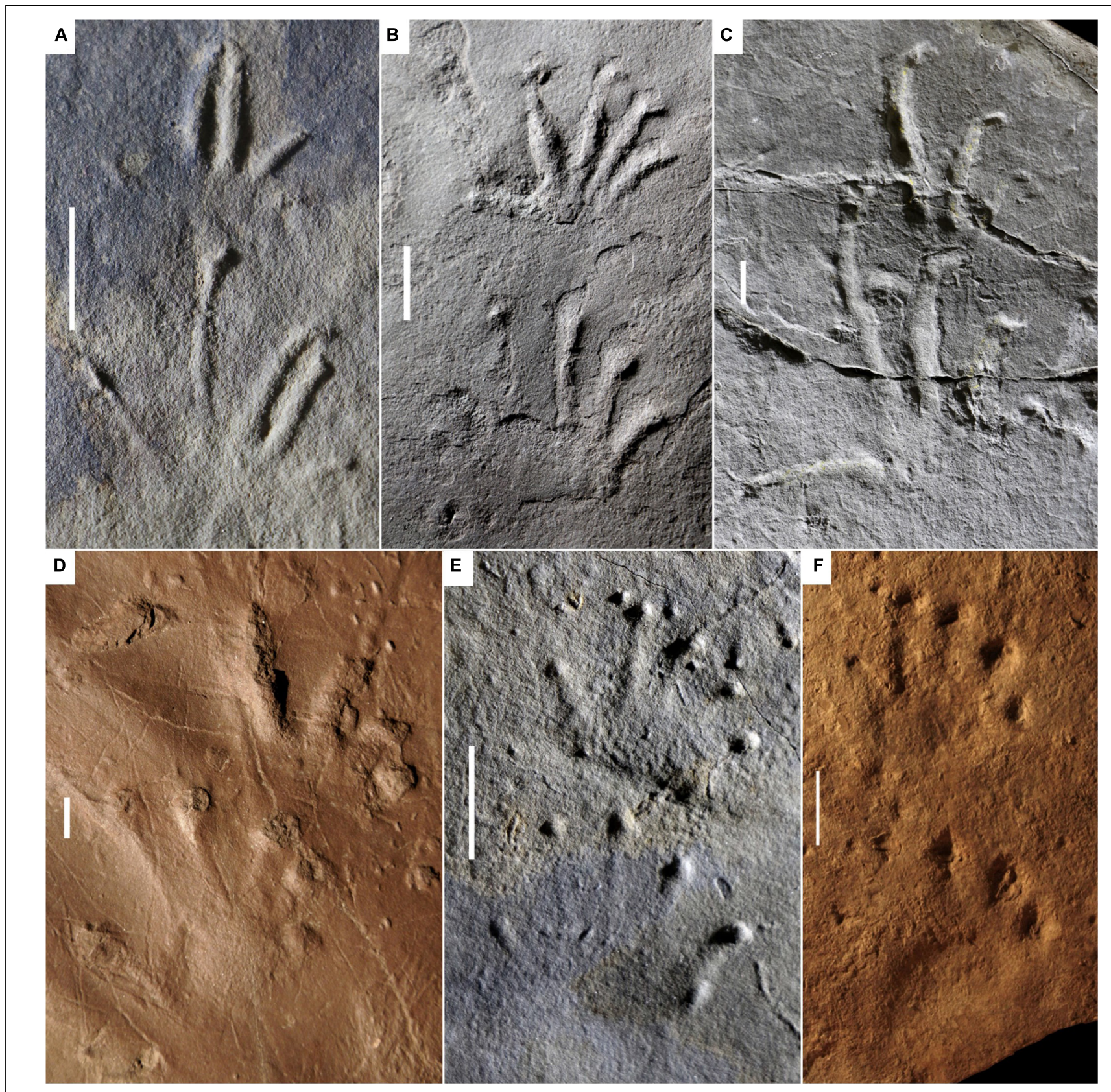

FIGURE 1 | Carboniferous ichnotaxa attributed to reptiles (A-C) and anamniote reptiliomorphs (D-F). (A) NMMNH P-31746-7. Notalacerta missouriensis, right pes-manus couple, convex hyporelief. McAlester Formation, Oklahoma. (B) NSM 997 GF 30.6. Varanopus microdactylus, right pes-manus couple, convex hyporelief. Cape John Formation, Nova Scotia. (C) YPM 519. Dromopus lacertoides, left pes-manus couple, concave epirelief. Howard Limestone, Kansas. (D) NMMNH P-64276. Hylopus hardingi, right pes-manus couple, convex hyporelief. (E) NMMNH-NN 1. Amphisauropus kablikae, right pes-manus couple, convex hyporelief. McAlester Formation, Oklahoma. (F) KU-NN 1. Ichniotherium cottae, left pes-manus couple, concave epirelief. Rock Shale Member, Stanton Formation, Kansas. Scale bars (A-E) are $1 \mathrm{~cm}$, scale bar $(\mathbf{F})$ is $5 \mathrm{~cm}$.

orientation of the manus digit $\mathrm{V}$ imprint. The best-preserved bolosaurian pes is known from Eudibamus cursoris from the Cisuralian Tambach Formation of the Bromacker site, Germany (Figures 7E,F). The pes digits are more slender and more elongated than in Erpetonyx, especially the first phalangeal bones. Nevertheless, the proportions are similar, although Eudibamus is more ectaxonic. A relatively high ectaxony can be observed in some Cisuralian V. microdactylus tracks, notably also from the same locality of Eudibamus (e.g., Voigt, 2005). The marked ectaxony with reduced digit $\mathrm{I}$ and long pes digit $\mathrm{V}$, about as long as digit III, are in general agreement with $V$. microdactylus. The pes distal tarsal $\mathrm{V}$ is relatively angular (Figure 7E), and this is consistent with the forward-lateral orientation of pes digit $\mathrm{V}$ in $V$. microdactylus (Figure $\mathbf{7 B}$ ). The tarsal structure 

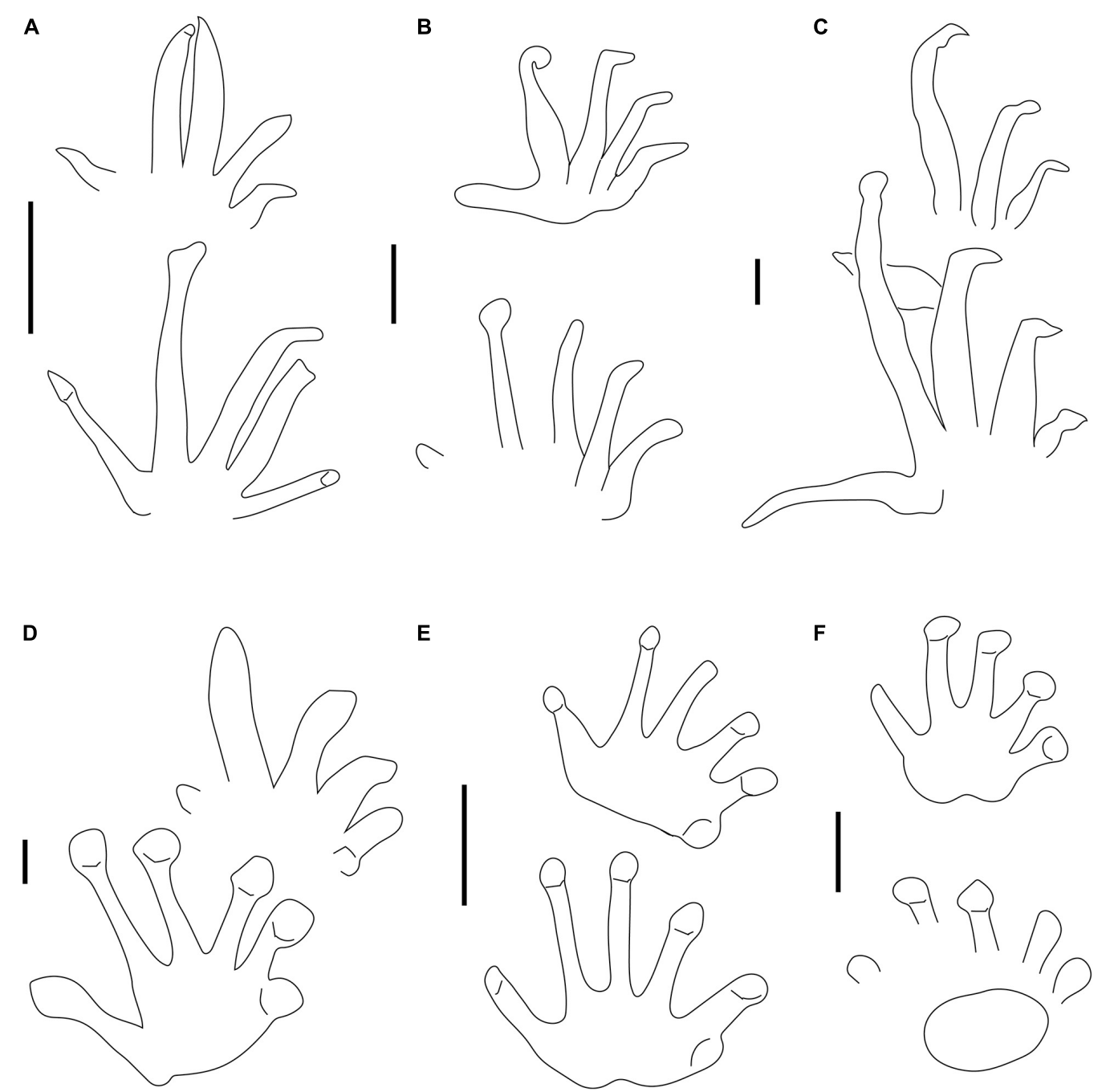

FIGURE 2 | Carboniferous ichnotaxa attributed to reptiles (A-C) and anamniote reptiliomorphs (D-F), interpretive drawings. (A-F) See caption of Figure 1. Scale bars (A-E) are $1 \mathrm{~cm}$, scale bar $(\mathbf{F})$ is $5 \mathrm{~cm}$.

is compact. The lateral centrale is fused with the astragalus, so the flexion was concentrated in the small area between this element and distal tarsals 1-3. This is in agreement with the deeper medial impression of the $V$. microdactylus sole (Figure 7C). Tarsal elements are generally larger in the ventral side (Figure 7E) rather than in the dorsal side (Figure 7F), suggesting a wedge-shape and flexion as a natural arrangement, in agreement with the short sole impression of $V$. microdactylus (Figure 7B). The overlapping of metatarsal from I to $\mathrm{V}$ is clear (Figures 7E,F), and consistent with the lateral overlapping of the digit imprint base seen in V. microdactylus (Figure 7B). The manus is incompletely preserved but shows a relatively short digit $\mathrm{V}$ compared to digit IV. This is in agreement with the digit $\mathrm{V}$ imprint proportions of $V$. microdactylus. Eudibamus has been regarded as a fast-moving and facultatively bipedal reptile (Berman et al., 2000). In the track record of Varanopus, bipedality is not observed, but complete primary overstep of the pes on the manus and very high pace angulation $\left(160^{\circ}\right)$ are known from the ichnospecies V. curvidactylus from Cisuralian eolian units of Arizona (Marchetti et al., 2019c). Though associated with downhill locomotion, this trackway pattern testifies to a trackmaker capable of a very fast gait, certainly the fastest known of the Carboniferous and Cisuralian tetrapod trackmakers.

\section{Tracks Attributed to Araeoscelids and Varanopids}

Dromopus lacertoides (Geinitz, 1861) (Figures 1C, 2C, and 8).

\section{Description}

Semidigitigrade, pentadactyl, ectaxonic footprints of a small- to medium-sized quadruped (pes foot length $44-75 \mathrm{~mm}, 60 \mathrm{~mm}$ on average). The manus is about $1 / 5$ shorter than the pes but shows identical morphology and proportions. Digit imprints are long, slender, distally tapering and end in triangular claw marks, directed medially. They may show elliptical digital pads. Digits 

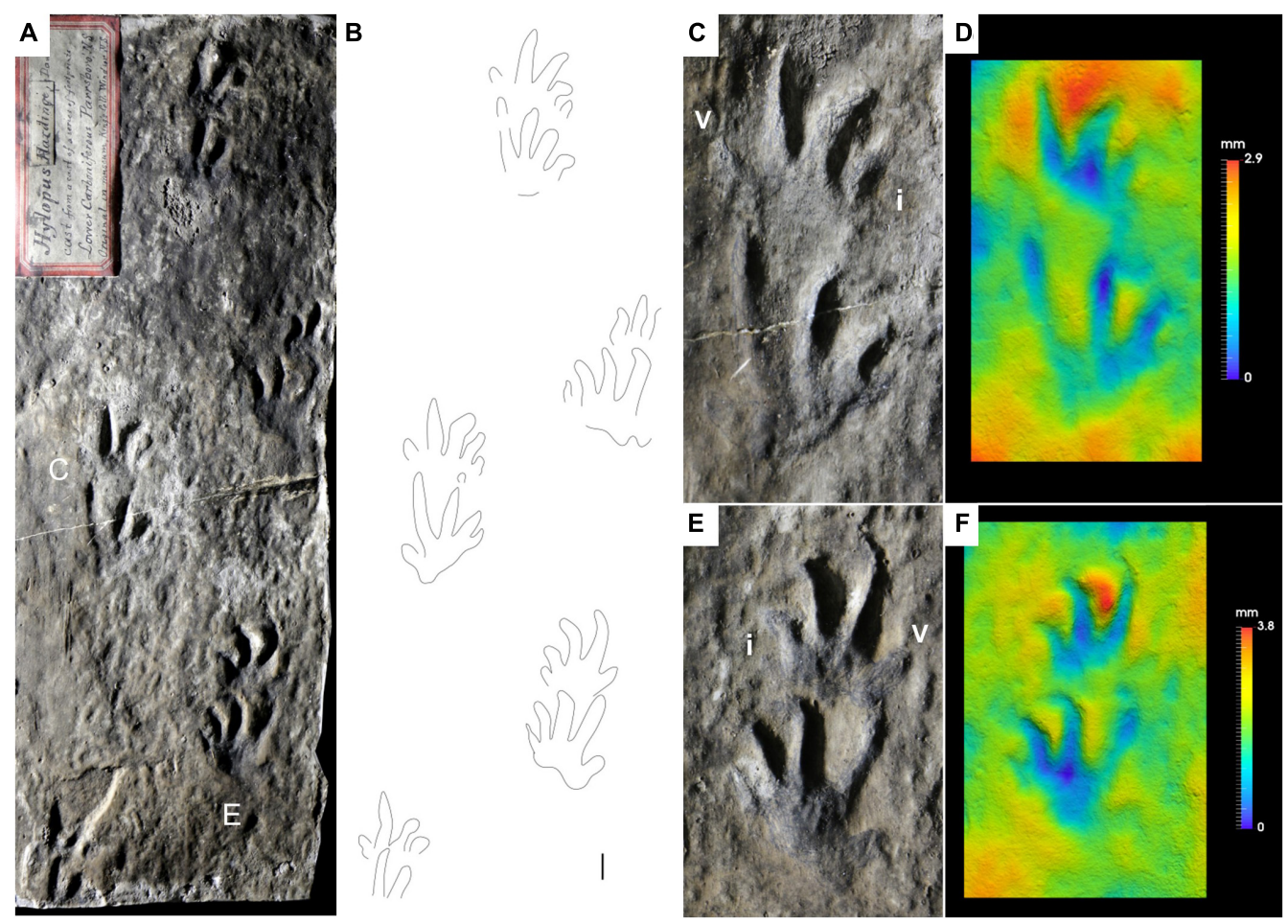

FIGURE 3 | Carboniferous anamniote reptiliomorph tracks, Hylopus hardingi. (A) NBMG 3060, "plastotype" of Hylopus hardingi, trackway, concave epirelief. Parrsboro Formation, Nova Scotia. (B) Interpretive drawing of (A). (C) Enlargement of (A). Right pes-manus couple. (D) False-color depth map of (C). (E) Enlargement of (A). Left pes-manus couple. (F) False-color depth map of (E). Manual digits indicated by Roman numbers. Scale bar is $1 \mathrm{~cm}$.

I-IV are medially and distally curved and are tightly grouped, showing a marked proximal-lateral superimposition. Digit length markedly increases between digit I and IV imprints. Digit V is proximal, straight, oriented laterally and of intermediate length between digit II and III imprints. The palm/sole is very short, shallow and rarely impressed. Footprints are semidigitigrade; the most deeply impressed digit imprints are II-IV, digit I and the bases of all other digits are very shallow and rarely impressed. Trackways are relatively broad and constituted by a simple alternating arrangement of pes-manus couples. The pace angulation is moderately high $\left(98-108,104^{\circ}\right.$ on average), the pes may partially overstep the manus proximally, the manus is parallel to the midline, and the pes is slightly oriented laterally. No tail and body impressions are observed.

\section{Remarks}

The ichnospecies "Saurichnites" lacertoides was erected by Geinitz (1861), based on material coming from the Cisuralian Proseèné-Formation of the Czech Republic. Pohlig (1892) introduced the new combination "Protritonichnites" lacertoides after the description of material from the Cisuralian Goldlauter Formation, Germany. Haubold (1971) introduced the new combination Dromopus lacertoides, because of the similarity of this material with Dromopus Marsh, 1894, from the Pennsylvanian Howard Limestone of Kansas. Subsequent studies generally used this combination (e.g., Haubold, 1984, 1996; Gand, 1988; Haubold et al., 1995; Haubold and Lucas, 2001; Voigt, 2005;
Lucas et al., 2011; Marchetti et al., 2015a,b; Voigt and Lucas, 2015, 2017), employing what is now a longstanding reversal of priority of Dromopus over "Protritonichnites." Haubold (1996) considered Dromopus agilis a junior synonym of Dromopus lacertoides; and this has generally been accepted by later studies. Some authors consider valid a further ichnospecies, Dromopus didactylus (Moodie, 1930) from the Cisuralian Choza Formation of Texas (Sarjeant, 1971; Gand, 1988; Gand and Durand, 2006), based on a supposed larger distance between the bases of digit impressions IV and V and thus increased digitigrady. Voigt (2005) questioned this argument, because it is based on a criterion difficult to verify due to the rarity of completely impressed footprints of Dromopus. Haubold and Lucas $(2001,2003)$ considered D. didactylus a junior synonym of Dromopus palmatus (Moodie, 1929) from the same formation. It is evident that a comprehensive revision of these ichnospecies is needed in order to verify possible synonymies and their relationship with morphologically-similar ichnotaxa such as Tambachichnium schmidti Müller, 1954.

The ichnotaxon Dromopus lacertoides is a relatively common form in the Late Pennsylvanian of Europe and North America. A Kasimovian occurrence is known from the Enville Member of the Salop Formation, United Kingdom (Haubold and Sarjeant, 1973; Meade et al., 2016). This age is based on late Westphalian D macrofloras found in the comformably underlying Halesowen Formation and sparse macrofloras of possible early Stephanian age within the Salop Formation (Cleal, 2008). Gzhelian occurrences are known from 

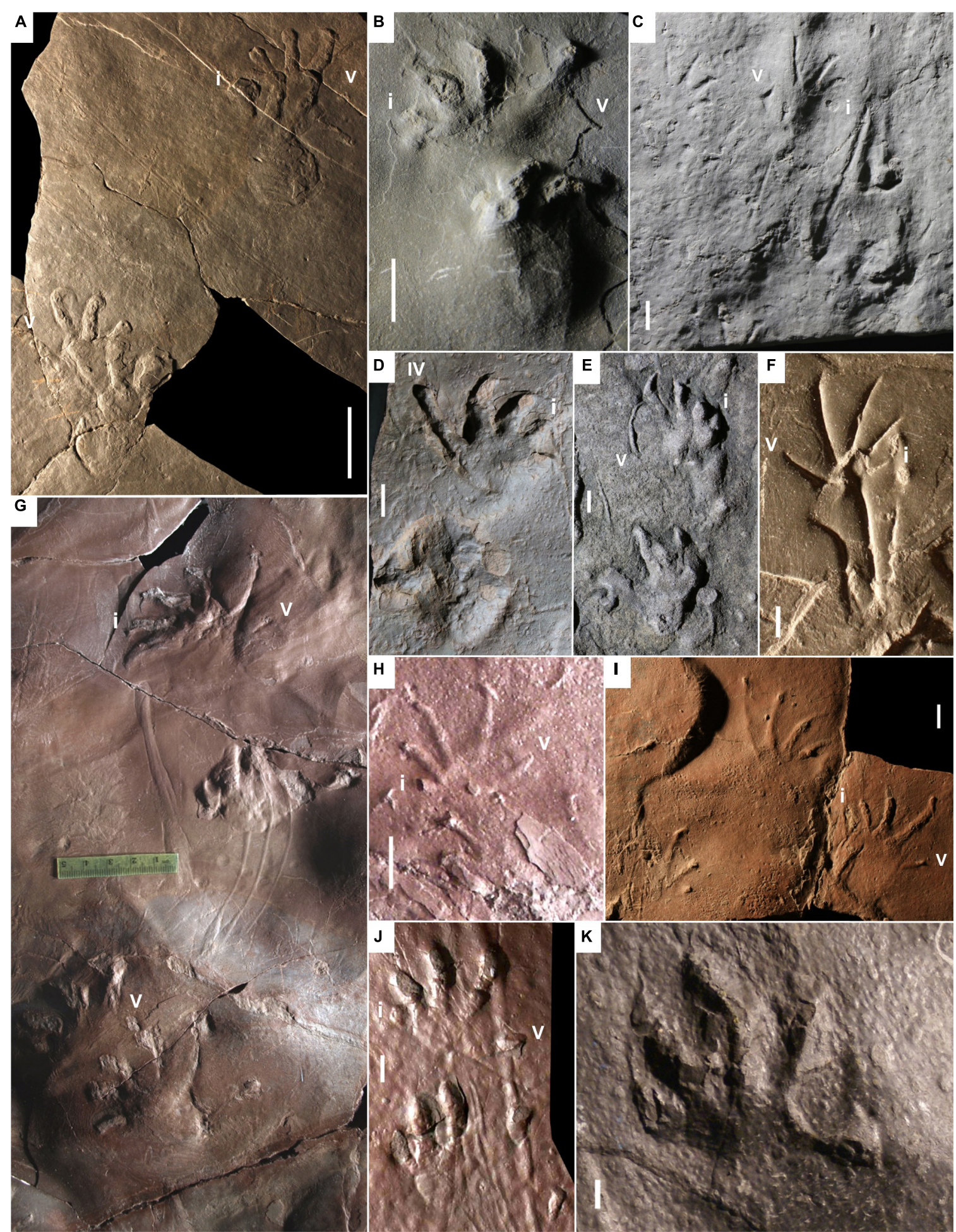

FIGURE 4 | Carboniferous anamniote reptiliomorph tracks, additional material of Hylopus hardingi. (A) MCZ 267, two consecutive pes-manus couples, convex hyporelief. West Bay Formation, Nova Scotia. (B) NSM 008GF031.142, left pes-manus couple, convex hyporelief. Joggins Formation, Nova Scotia. (C) NSM 008GF039.336. Two left pes-manus couples. Joggins Formation, Nova Scotia. (D) NBMG 10128-1, right pes-manus couple, convex hyporelief. Enrage Formation, New Brunswick. (E) NBMG 14143, right pes-manus couple, convex hyporelief. Grande Anse Formation, New Brunswick. (F) UCM 263 JT, left pes-manus couple, concave epirelief. Pottsville Formation, Alabama. (G-J) Mauch Chunk Formation, Pennsylvania. (G) SMP-IP 8789, two consecutive left pes-manus couples, impression of digit I basal pad, tail impression and digit scratches, convex hyporelief. (H) SMP-VP 2325, left pes-manus couple, convex hyporelief. (I) MCZ-NN 1, isolated tracks, convex hyporelief. (J) RPM 1011, left pes-manus track, convex hyporelief. (K) DBM-NN 1. Left pes imprint, convex hyporelief. Germany. Manual digits indicated by Roman numbers. Scale bar $(\mathbf{A})$ is $5 \mathrm{~cm}$, scale bars $\mathbf{( B - F , H - K )}$ are $1 \mathrm{~cm}$. 
the Howard Limestone of Kansas (Marsh, 1894; Baird, 1952), the Flechtingen, Georgenthal, and Ilmenau formations of Germany (Voigt, 2012) and possibly the Remigiusberg Formation of Germany (Voigt et al., 2019). A Gzhelian-Asselian occurrence is known from the Cape John Formation of Nova Scotia, originally assigned to Dromopus agilis (Van Allen et al., 2005).

\section{Trackmaker Attribution}

The long, curved, tapering digit imprints with sharp claw marks, the strong ectaxony, and the digitigrady are generally consistent with an attribution of Dromopus lacertoides to reptiles. In the first descriptions (Geinitz, 1861; Marsh, 1894), Dromopus was attributed to Lacertilia because of its lacertoid appearance (i.e., long, curved and clawed digit imprints, marked ectaxony, pentadactyly). However, the oldest representatives of this group are Triassic. An attribution of Dromopus to basal reptiles, such as protorothyridids, has been also proposed (Haubold, 1971; Fichter, 1983). Nevertheless, protorothyridids and closely related forms, such as Hylonomus and capthorhinomorphs, are characterized by radiating and non-overlapping metatarsals (e.g., Carroll, 1964, 1969; Sumida, 1989; Holmes, 2003), which is evidently in contrast with the proximally overlapping digit imprints of Dromopus (Figure 8B). This is clearly not an extramorphological feature because it occurs consistently in optimally preserved material, regardless of gait variability and lithofacies. An attribution to other forms with lacertoid appearance such as the bolosaurian Eudibamus cursoris has also been proposed (Voigt, 2005). Nevertheless, the manus shows a markedly shorter digit V compared to the pes, unlike Dromopus lacertoides, in which the pes and manus imprints have very similar morphology and proportions. Also, the pes distal tarsal V is angular, and this is not consistent with the laterally directed pes digit $\mathrm{V}$ imprint of $D$. lacertoides. Moreover, the fused astragalus and lateral centrale are not in agreement with the digitigrady of the $D$. lacertoides medial pes imprint. Because other parareptile forms also show these features, an attribution of Dromopus lacertoides to parareptiles is currently not well supported.

Nopcsa (1923) proposed an attribution to Araeoscelidia such as Araeoscelis, because of similar appendicular morphology and age. This has been the most accepted attribution so far (Haubold, 1971; Gand, 1988; Haubold et al., 1995; Haubold and Lucas, 2003; Voigt, 2005; Voigt and Lucas, 2015; Lucas, 2018; Marchetti et al., 2015a,b). The relative lengths of the pes and manus digits of Petrolacosaurus kansensis (Figure 8F) and the pes digits of Araeoscelis gracilis (Figure $\mathbf{8 G}$ ) are generally consistent with the marked ectaxony of $D$. lacertoides. Most of the tarsal and carpal elements are characterized by a marked, wedge-shape morphology (e.g., Reisz, 1981; Reisz et al., 1984), in agreement with the digitigrady of Dromopus lacertoides. Forward flexion was possible throughout the whole tarsus and carpus, also between the lateral centrale and the astragalus, different from captorhinomorphs and parareptiles. This would explain why Dromopus lacertoides is not characterized by a deeper medial impression of the sole (Figure 8C); the medial flexion of the trackmaker tarsus could be better accommodated by the presence of a further articulation. Metatarsals and metacarpals are laterally overlapped, and this is consistent with the digit base overlap of
D. lacertoides (Figure 8B). The morphology and proportions of some varanopid appendicular skeletons are virtually identical to those of araeoscelids, therefore they could have been producers of Dromopus (Spindler et al., 2018, 2019). This is the case of the relatively small forms such as Ascendonanus, Cabarzia, and Mesenosaurus, characterized by marked ectaxony in both the pes and manus. Mesenosaurus romeri has digit proportions and arrangement consistent with Dromopus lacertoides (Figure $\mathbf{8 H}$ ). Quite interestingly, a specimen preserves an articulated pes in flexion, which clearly shows the mobility between astragalus, lateral centrale and tarsals 1-3 and laterally overlapping metatarsals (Spindler et al., 2019; Figure 10h), all features consistent with $D$. lacertoides. All varanopids show an angled fifth toe, a feature in common with araeoscelids and in agreement with the laterally oriented digit $\mathrm{V}$ imprints of Dromopus lacertoides (Spindler et al., 2019). Larger forms of varanodontine varanopids such as Aerosaurus, Varanops, and Tambacarnifex have instead a pes more robust and less ectaxonic than the manus, therefore they could have instead been the producers of Tambachichnium Müller, 1954.

\section{Quantitative Comparison of Trackway Patterns \\ Variation Among Reptile Tracks}

Trackways of Dromopus and Varanopus from Gzhelian deposits mostly fall within the ranges of Cisuralian trackways from the Thuringian Forest assigned to the same ichnogenera (Figure 9). Samples of both ichnogenera occupy different but adjacent variation spaces. In (normalized) pace length, however, which is usually distinct in the Dromopus and Varanopus reference samples from the Cisuralian, the Gzhelian trackways overlap (Figure 9A). Notalacerta trackways from the Moscovian McAlester Formation can be distinguished from the Bashkirian Notalacerta based on several trackway parameters, especially pace angulation, stride length, orientation of the pes imprints, position and orientation of the manus imprints in relation to the pes imprints and glenoacetabular distance (Figures 9A,B,D-H). In some features, such as pace angulation, stride, position and orientation of the manus imprints (in relation to pes imprints), Moscovian Notalacerta is closer to the Gzhelian and Cisuralian samples of Dromopus and Varanopus than Bashkirian Notalacerta (Figures 9A,D,E,H).

\section{Similarity Between Hylopus and Reptile Tracks}

The ranges of the Mississippian to early Bashkirian Hylopus $(n=11)$ and late Bashkirian Hylopus $(n=3)$ samples are overlapping only in some trackway measures and are clearly distinct in others. The single Hylopus trackway from the Moscovian of Germany does not fit with either sample (see diamond symbol in Figures 9A,B; phi symbol in e.g., Figures 9C$\mathbf{H})$. There are notable similarities between late Bashkirian Hylopus and Bashkirian Notalacerta tracks-among others, low pace angulations, inward positioned manus and outwardoriented pes imprints are similar. Some characteristics present in late Bashkirian Hylopus tracks, such as the moderate stride length, a short pes-manus distance and a high deviation between manus and pes imprint orientations, are also shared by Gzhelian 


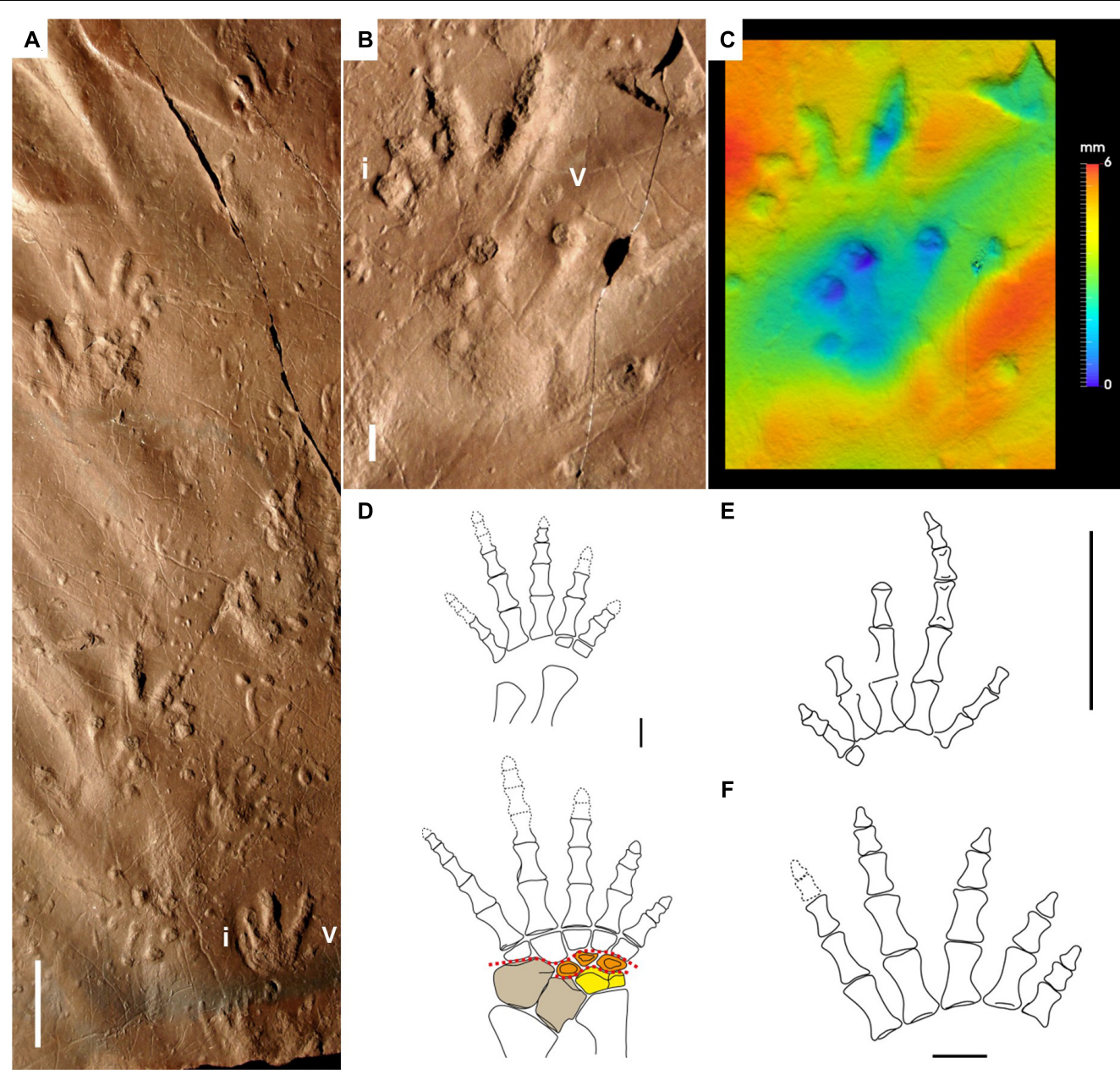

FIGURE 5 | Carboniferous anamniote reptiliomorph tracks and trackmakers: Hylopus hardingi (A-C) and stem tetrapods and anthracosaurids (D-F). (A) NMMNH P-64276, trackway, convex hyporelief. Mauch Chunk Formation, Pennsylvania. (B) NMMNH P-64276, right pes-manus couple, concave epirelief. (C) False-color depth map of (B). (D) Proterogyrinus scheelei, reconstruction of left pes and manus, dorsal side. From Holmes (1984), modified. Manual digits indicated by Roman numbers. Centralia in orange, tibiale in yellow and intermedium and fibulare in brown. Red dotted lines represent the possible articulations within the tarsus.

(E) Casineria kiddi, reconstruction of right manus, dorsal side. From Paton et al. (1999), modified. (F) Greererpeton burkemorani, reconstruction of left pes, dorsal side. From Clack (2002), modified. Scale bar (A) is $5 \mathrm{~cm}$, scale bars (B,D-F) are $1 \mathrm{~cm}$.

and Cisuralian Dromopus tracks. Mississippian tracks of Hylopus are characterized by very narrow gauges (normalized pedal gauge width $<1.8$ ), a feature shared by Dromopus and several Notalacerta trackways (Figure 9C). In certain measures, such as gauge width and pes-manus distance, the ranges of Varanopus and late Bashkirian Hylopus overlap (Figures 9C,G).

\section{MANOVA Results}

In standard multivariate normality tests (Mardia tests, Doornik and Hansen omnibus) the null hypothesis (multivariate normality) was not rejected, and we employed MANOVA for both test scenarios (each with 4 groups, 6 variables). In both cases, significant differences were found: For the analysis including Mississippian-early Bashkirian Hylopus, late Bashkirian Hylopus, Bashkirian Notalacerta and Moscovian Notalacerta as four separate groups, the null hypothesis (similarity; that all samples come from the same statistical population) was rejected for the overall dataset ( $p$-value for
Wilks' lambda: $3.73^{*} 10^{-6}$; $p$-value for Pillai's trace: $3.45^{*} 10^{-5}$ ), but, given the small sample sizes (3-11 per group), pairwise testing did not find significant differences between individual groups. According to Mahalanobis distances, the Bashkirian and Moscovian samples of Notalacerta and the two samples of Hylopus are well separated from one another, but also for other pairings the values are relatively high (Figure 10A). For the second analysis including Bashkirian Notalacerta, Moscovian Notalacerta, Gzhelian-Cisuralian Dromopus and Gzhelian-Cisuralian Varanopus as four separate groups, the overall test result was highly significant ( $p$-value for Wilks' lambda: $5.421^{*} 10^{-8} ; p$-value for Pillai's trace: $1.774^{*} 10^{-6}$ ) and differences for the pairings Dromopus/Varanopus and Dromopus/Moscovian Notalacerta were found to be significant. Low Mahalanobis distances for the pairings Varanopus/Moscovian Notalacerta and Dromopus/Bashkirian Notalacerta indicate that the respective trackway patterns are relatively similar (Figure 10A). 




\section{LDA Results}

In accordance with the MANOVA results, the Hylopus and Notalacerta samples can be separated quite well through linear discriminant analysis based on the same set of six variables (Figure 10B; incorrectly classified trackways: 1/24, 4.2\%). The single Moscovian trackway assigned to Hylopus (Specimen SGM/SA) and two Gzhelian Varanopus trackways were classified as belonging to the Moscovian Notalacerta group, whereas the Gzhelian Dromopus trackways fell into the range of Mississippian-early Bashkirian Hylopus (Table 4). When the LDA included only the two Notalacerta samples as predefined groups, both the Dromopus and Varanopus trackways from Gzhelian deposits were classified as Moscovian Notalacerta. A LDA including the two Notalacerta samples and the Cisuralian Dromopus and Varanopus samples as separate groups, found only one specimen $(1 / 28,3.57 \%)$ incorrectly classified, and one of the Gzhelian Varanopus specimens (NSM 99 GF 34b) fell in the range of Moscovian Notalacerta (Table 4, last column). The consideration of combined Gzhelian-Cisuralian Varanopus and Dromopus groups did not have much of an effect on the LDA result $(2 / 32$ specimens $=6.25 \%$ were wrongly classified: Figure 10C).

\section{FUNCTIONAL AND PHYLOGENETIC IMPLICATIONS OF TRACKWAY PATTERN VARIATION}

\section{Hylopus hardingi}

According to our analysis of their trackway patterns, the assignment of Mississippian and Pennsylvanian Hylopus tracks 


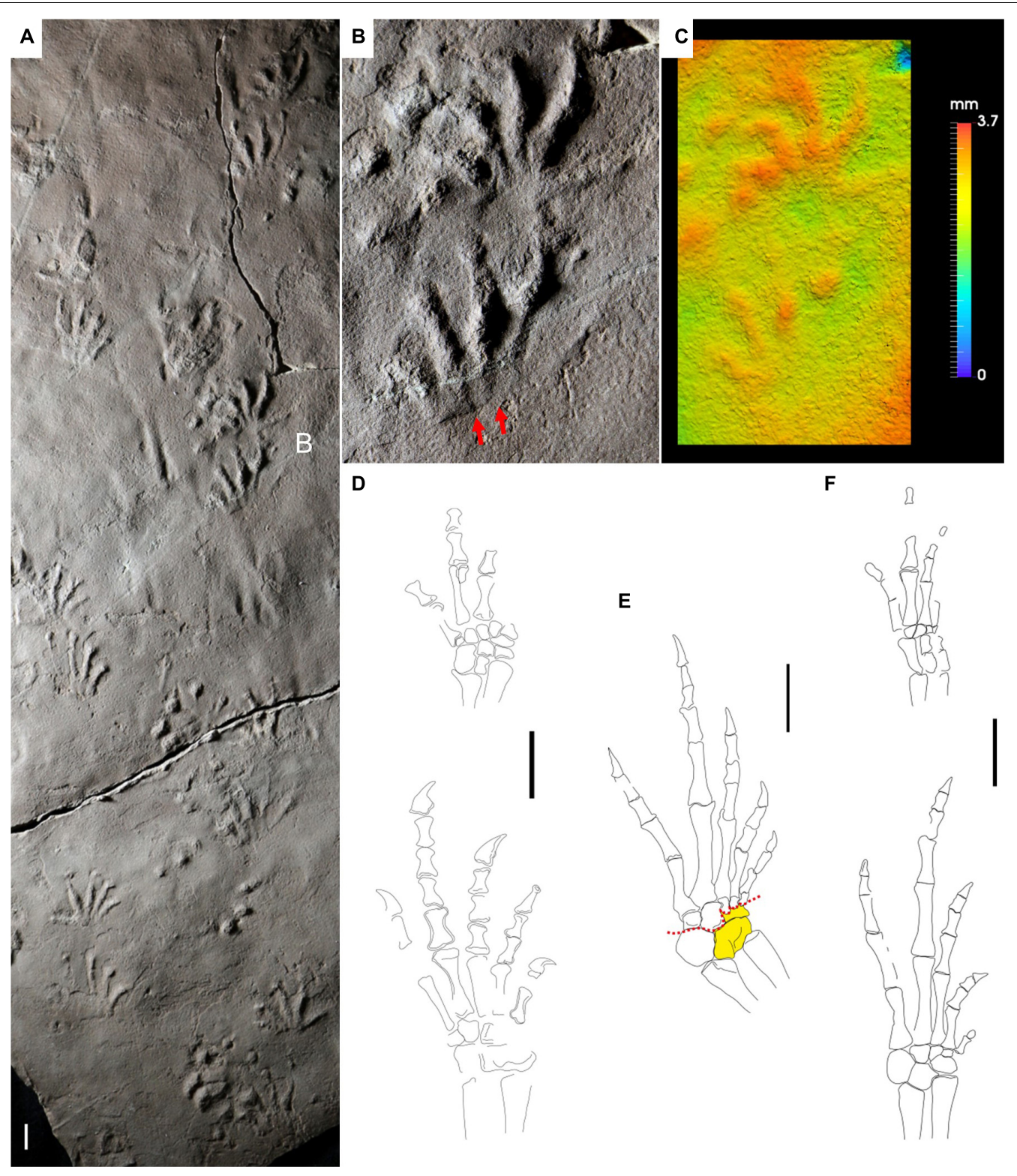

FIGURE 7 | Carboniferous reptile tracks and trackmakers: Varanopus microdactylus (A-C) and bolosaurian parareptiles (D-F). (A) NSM 997 GF 30.6. Trackway, convex hyporelief. Cape John Formation, Nova Scotia. (B) Enlargement of (A), left pes-manus couple, convex hyporelief. Red arrows indicate the proximal-lateral digit overlap. (C) False-color depth map of (B). (D) Erpetonyx arsenaultorum, reconstruction of right pes and left manus, dorsal side. Based on ROM 55402. (E,F) Eudibamus cursoris. (E) Reconstruction of right pes, ventral side. Based on MNG 12895. Astragalus and lateral centrale in yellow (single block). Red dotted lines represent the possible articulations within the tarsus. (F) Reconstruction of left pes and manus, dorsal side. Based on MNG 8852 . Scale bars are $1 \mathrm{~cm}$.

to a homogeneous producer group is not endorsed. Furthermore, the observation that some of the Mississippian Hylopus specimens have a more "amniote-like" trackway pattern than the younger (late Bashkirian) Hylopus trackways-with narrower gauges, higher pace angulations $\left(>100^{\circ}\right)$ and more closely grouped set pes and manus imprints (Figure 10D)-would be in agreement with the hypothesis that Hylopus tracks covered in this approach represent disparate locomotion styles, ecologies and/or degrees of terrestriality. Evidence supporting a more exact trackmaker assignment for different Hylopus samples may help us to define whether the observed variability in Hylopus trackways represents a morphological and/or ecological differentiation among closely related trackmakers or, as an alternative, entirely different episodes of terrestrialization close to the origin of amniotes, within more basal anamniote reptiliomorphs or even in more distantly related tetrapod groups.

\section{Notalacerta missouriensis}

The most notable signal found in our quantitative comparison of early reptilian tracks concerns the homogeneity of trackways assigned to Notalacerta: with their more inwardpositioned manus imprints, outward-rotated pes imprints, 


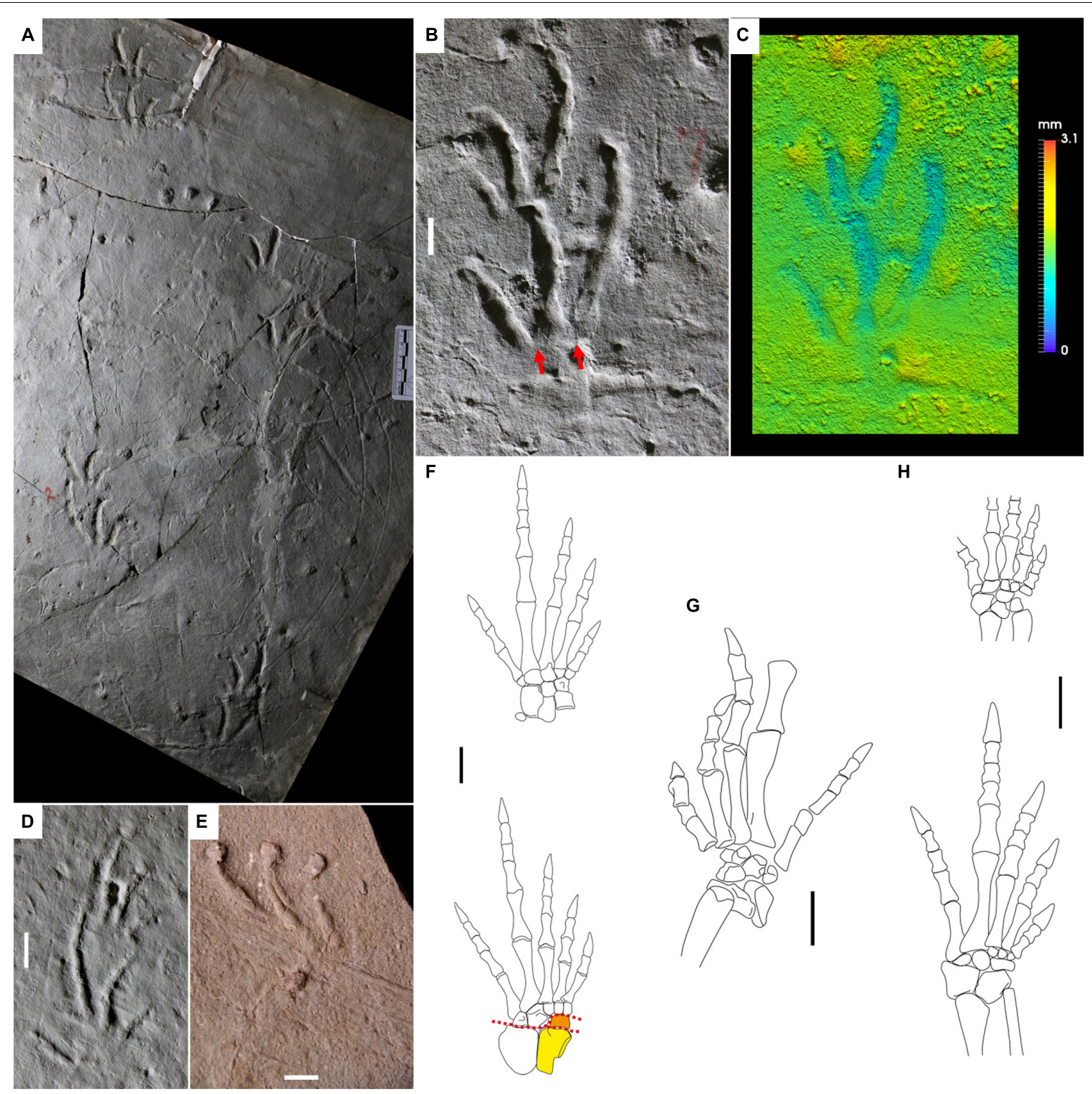

FIGURE 8 | Carboniferous reptile tracks and trackmakers: Dromopus lacertoides (A-E) and araeoscelid (F,G) and non-varanodontine varanopids (H). (A) YPM 519. Holotype of Dromopus "agilis." Trackway, concave epirelief. Howard Limestone, Kansas. (B) YPM 519. Right pes-manus couple, concave epirelief. Howard Limestone, Kansas. Red arrows indicate the proximal-lateral digit overlap. (C) False-color depth map of (B). (D) NSM 009 GF 012. Right pes-manus couple, convex hyporelief, plaster cast. Cape John Formation, Nova Scotia. (E) BIRUG BU 5283. Right footprint, convex hyporelief. Enville Member, Salop Formation,

United Kingdom. (F) Petrolacosaurus kansensis, reconstruction of left pes and manus, dorsal side. From Reisz (1981), modified. Astragalus in yellow, lateral centrale in orange. Red dotted lines represent the possible articulations within the tarsus. (G) Araeoscelis gracilis, reconstruction of right pes, convex hyporelief. From Reisz et al. (1984), modified. (H) Mesenosaurus romeri, reconstruction of left pes and manus, dorsal side. From Spindler et al. (2019), modified. Scale bars are $1 \mathrm{~cm}$.

low pace angulations and short strides, the Bashkirian Notalacerta trackways look much more "amphibianlike" than the younger Notalacerta trackways from the Moscovian McAlester Formation. Interestingly, the Bashkirian Notalacerta are also the earliest reptile tracks and co-occur with the most "amphibian-like" trackways of Hylopus, possibly testifying to similar palaeoecological adaptations of the reptile and anamniote reptiliomorph groups in the Early Pennsylvanian.
The four Gzhelian trackways assigned to Dromopus and Varanopus (specimens NSM 009 GF 012, YPM 519, NSM 997 GF 30.6, and NSM 99 GF 34) share trackway patterns that are similar to those of Moscovian Notalacerta (see Table 3 and Figure 10C). This similarity could either indicate a closer relationship of Moscovian Notalacerta producers with the trackmakers of Dromopus and Varanopus than with Bashkirian Notalacerta (Figure 10D) or a convergent emergence of similar trackway patterns within the trackmakers of Notalacerta and 
- Hylopus (Miss.-E. Bash.)
- Hylopus (L. Bashkirian)
+ Notalacerta (Bashkirian)
$\times$ Notalacerta (Moscovian)
- Dromopus (Gzhelian)
$\square$ Dromopus (Cisuralian)
- Varanopus (Gzhelian)
$\Delta$ Varanopus (Cisuralian)
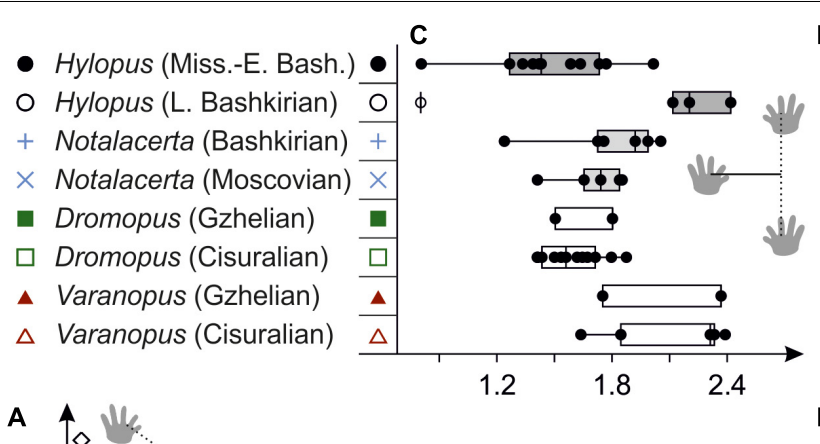
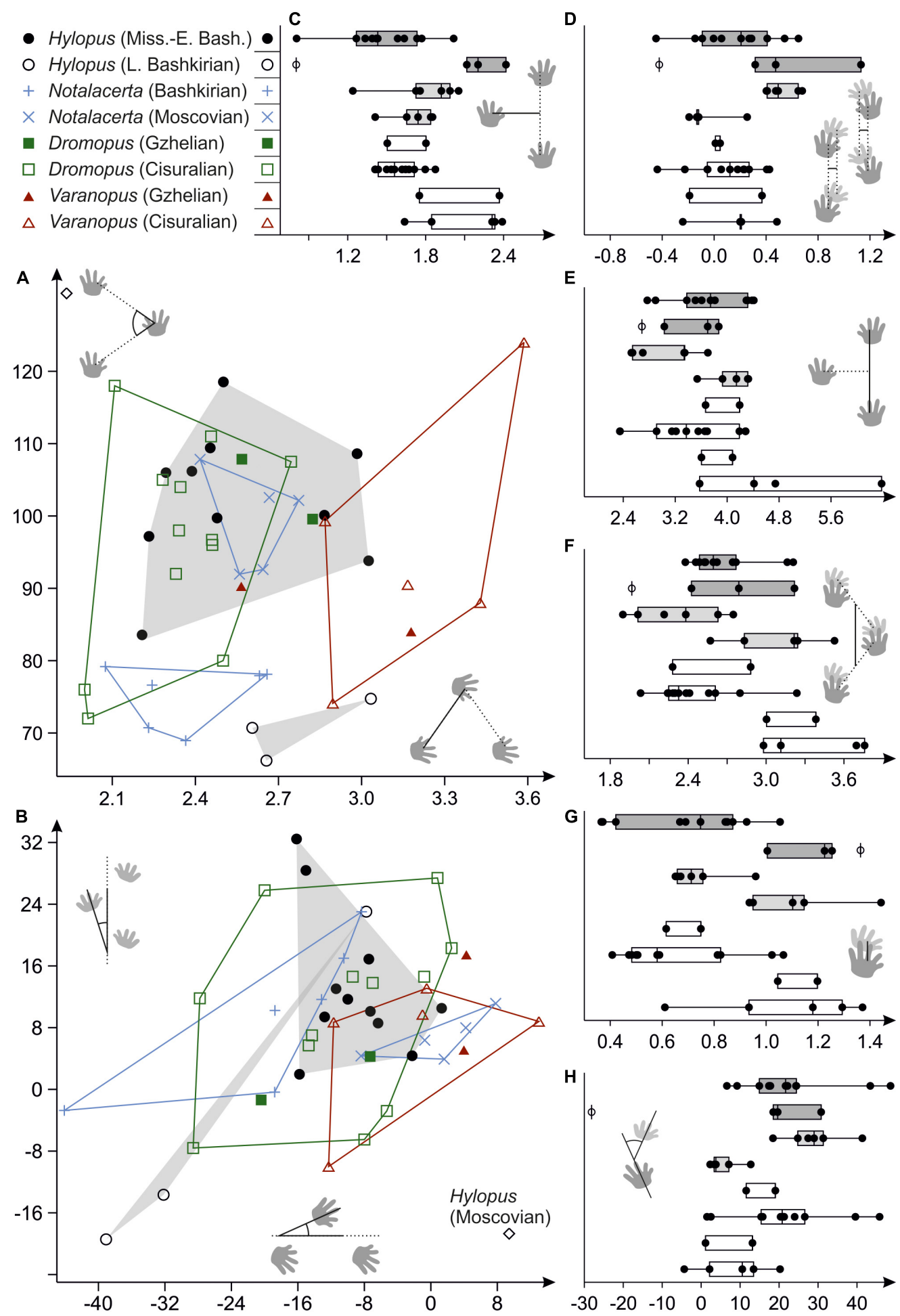

FIGURE 9 | Variability of trackway measures in Hylopus, Notalacerta, Dromopus and Varanopus from Mississippian to Pennsylvanian deposits and two Cisuralian reference samples (Supplementary Material), depicted as bivariate plots (A,B) and combined scatter plots/box-and-whisker plots (C-H). (A) Pedal pace angulation (vertical axis) vs. pedal pace length (horizontal axis); (B) orientation for the manus imprints (vertical axis) vs. orientation of the pes imprints (horizontal axis) (with respect to the trackway midline; in degree); (C) normalized pedal gauge width; (D) normalized deviation between manual and pedal gauge width; (E) normalized pedal stride length; (F) normalized pedal gauge width; (G) normalized pes-manus along-track distance; (H) normalized deviation between manus and pes imprint orientation (in degree). The sole trackway of Hylopus from the Moscovian of Germany is represented by the empty circle (phi symbol) in (C-H). 


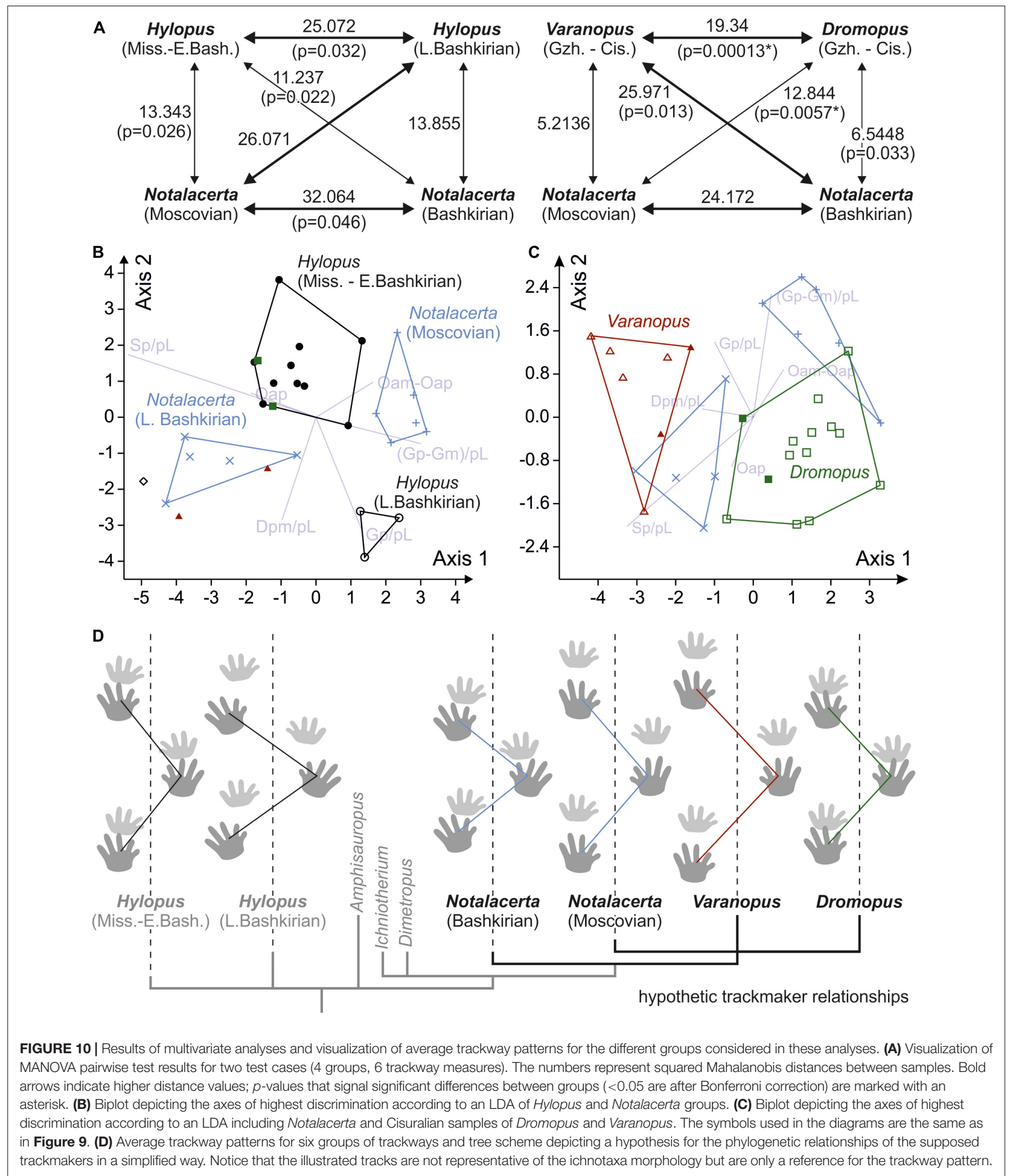

those of the later occurring Dromopus and Varanopus. Our data challenge the idea that the Carboniferous Notalacerta tracks necessarily represent one narrowly defined group of trackmakers within the protorothyridid reptiles (see also discussion in Marchetti et al., 2020a, who included also Hylonomus and Thuringothyris as possible producers). Given the similarity of 
the supposed parareptile track type Varanopus to Moscovian Notalacerta trackways in some parameters (imprint orientation angles, glenoacetabular length, distance between successive pes and manus imprints, Figures $\mathbf{9 B}, \mathbf{F}-\mathbf{H}$ ), the hypothesis that Notalacerta tracks could include stem group members of the Reptilia seems reliable (see also hypothetical trackmaker tree in Figure 10D).

\section{Dromopus lacertoides vs. Varanopus microdactylus}

The distinctiveness of Gzhelian to Cisuralian Dromopus and Varanopus trackways, which is also reflected by the results of our variance analysis (Figure 10A), becomes particularly visible in two critical parameters: Varanopus trackways display notably higher pace lengths than Dromopus trackways. Also, with few exceptions, their pes and manus imprints are placed more distantly and rarely overlap. Notwithstanding their similar pace angulations ranges (Figure 9A), these differences arguably denote entirely different specialized postures and possibly different walking gaits and/or proportions of the Varanopus and Dromopus trackmakers. Despite their lower (normalized) stride lengths, the Dromopus tracks do not necessarily represent slower trackmakers, nor does the wide gauge in Varanopus tracks indicate a more "primitive," sprawling posture. Their comparison with older Pennsylvanian reptile trackway patterns suggests that both track types represent derived reptilian locomotion styles.

\section{ORIGIN AND EARLY EVOLUTION OF REPTILES IN THE TRACK AND SKELETAL RECORDS}

\section{Early Pennsylvanian: Earliest Reptiles}

The comprehensive revision of the ichnotaxon Hylopus hardingi, including a discussion of similar material and a trackmaker attribution based on morphofunctional features, allows us to

TABLE 4 | Classification of Gzhelian Dromopus and Varanopus trackways in linear discriminant analyses with different reference groups.

\begin{tabular}{|c|c|c|c|}
\hline $\begin{array}{l}\text { Groups } \\
\text { considered in } \\
\text { the LDA }\end{array}$ & $\begin{array}{l}\text { Notalacerta (2x) } \\
\text { and Hylopus }(2 \mathrm{x})\end{array}$ & Notalacerta (2x) & $\begin{array}{l}\text { Notalacerta }(2 \mathrm{x}) \text {, } \\
\text { Dromopus and } \\
\text { Varanopus } \\
\text { (Cisuralian) }\end{array}$ \\
\hline $\begin{array}{l}\text { correct } \\
\text { classification }\end{array}$ & $87.5 \%(21 / 24)$ & $100 \%(11 / 11)$ & $96.43 \%(27 / 28)$ \\
\hline $\begin{array}{l}\text { NSM } 009 \text { GF } \\
012 \\
\text { (Dromopus) }\end{array}$ & $\begin{array}{l}\text { Hylopus } \\
\text { (Mississippian) }\end{array}$ & $\begin{array}{l}\text { Notalacerta } \\
\text { (Moscovian) }\end{array}$ & $\begin{array}{l}\text { Dromopus } \\
\text { (Cisuralian) }\end{array}$ \\
\hline $\begin{array}{l}\text { YPM } 519 \\
\text { (Dromopus) }\end{array}$ & $\begin{array}{l}\text { Hylopus } \\
\text { (Mississippian) }\end{array}$ & $\begin{array}{l}\text { Notalacerta } \\
\text { (Moscovian) }\end{array}$ & $\begin{array}{l}\text { Dromopus } \\
\text { (Cisuralian) }\end{array}$ \\
\hline $\begin{array}{l}\text { NSM } 997 \text { GF } \\
30.6 \\
\text { (Varanopus) }\end{array}$ & $\begin{array}{l}\text { Notalacerta } \\
\text { (Moscovian) }\end{array}$ & $\begin{array}{l}\text { Notalacerta } \\
\text { (Moscovian) }\end{array}$ & $\begin{array}{l}\text { Varanopus } \\
\text { (Cisuralian) }\end{array}$ \\
\hline $\begin{array}{l}\text { NSM } 99 \text { GF } \\
34 \mathrm{~b} \\
\text { (Varanopus) }\end{array}$ & $\begin{array}{l}\text { Notalacerta } \\
\text { (Moscovian) }\end{array}$ & $\begin{array}{l}\text { Notalacerta } \\
\text { (Moscovian) }\end{array}$ & $\begin{array}{l}\text { Notalacerta } \\
\text { (Moscovian) }\end{array}$ \\
\hline
\end{tabular}

exclude an attribution to amniote producers. Hylopus hardingi is instead attributed to anamniote reptiliomorphs, and we assign material from the late Namurian-early Langsettian Grande Anse, Tynemouth Creek and Enrage formations of New Brunswick and the late Namurian Port Hood Formation of Nova Scotia to this ichnotaxon. These specimens were initially considered as possible evidence of the earliest reptile tracks (Keighley and Pickerill, 1998; Wood and Miller, 2007; Falcon-Lang et al., 2007, 2010), but later questioned by other studies (Keighley et al., 2008; Fillmore et al., 2012; Lucas, 2019; Marchetti et al., 2019a, 2020a).

Accordingly, the oldest reptile footprints are represented by the ichnotaxon Notalacerta missouriensis, and they can be attributed to basal reptiles, including Hylonomus and protorothyridids (Marchetti et al., 2020a). To note, both Notalacerta missouriensis and the earliest known reptile, Hylonomus lyelli, come from the same formation and locality (Joggins Formation, UNESCO World Heritage Site, Joggins Fossil Cliffs, Joggins, Nova Scotia, Canada). The Joggins Formation is dated through sporomorphs as early Langsettian/Westphalian A, Bashkirian (e.g., Calder et al., 2006; Utting et al., 2010). No other skeletal records of reptiles are known from the Bashkirian. Nevertheless, Notalacerta missouriensis has been found in several Bashkirian localities: the early Langsettian Pottsville Formation of Alabama, the late Langsettian Lee Formation of Kentucky and Lancaster Formation of New Brunswick and the Langsettian of the Lower Coal Measures of Indiana (e.g., Chesnut et al., 1994; Haubold et al., 1995; Marchetti et al., 2020a). A further record is known from the late Bashkirian-early Moscovian (Westphalian B-C) Galmous Formation of Morocco (Lagnaoui et al., 2014). Thus, the tetrapod footprint record of reptiles expands the paleobiogeographic distribution of this group simultaneously just after their oldest record, encompassing localities from Alabama to Nova Scotia and North Africa (Figure 11), and is locally abundant (e.g., Alabama: Haubold et al., 2005). Since late Namurian units of Nova Scotia and New Brunswick do not include Notalacerta, it can be hypothesized that there was a Langsettian origin and radiation of basal reptiles in these areas, or a different and slightly older (late Namurian?) paleobiogeographic origin and a subsequent Langsettian radiation also encompassing Canadian units. This latter hypothesis would be supported by the early Langsettian record of Notalacerta missouriensis from the Pottsville Formation of Alabama, which is roughly time-equivalent with the Joggins Formation of Nova Scotia. Quite significantly, in Alabama, Nova Scotia and North Africa, basal reptile tracks (Notalacerta missouriensis) co-occur with anamniote reptiliomorph tracks (Hylopus hardingi).

\section{Late Pennsylvanian: Diversification of Reptiles}

The oldest record of parareptiles is constituted by Carbonodraco lundi, recently described from the late Moscovian Mazon Creek Lagerstätte located in the Francis Creek Shale of Ohio (Mann et al., 2019). This taxon has been classified as an acleistorhinid parareptile. This group has been recently revised, and all the other known finds come the Cisuralian of the United States and Brazil 


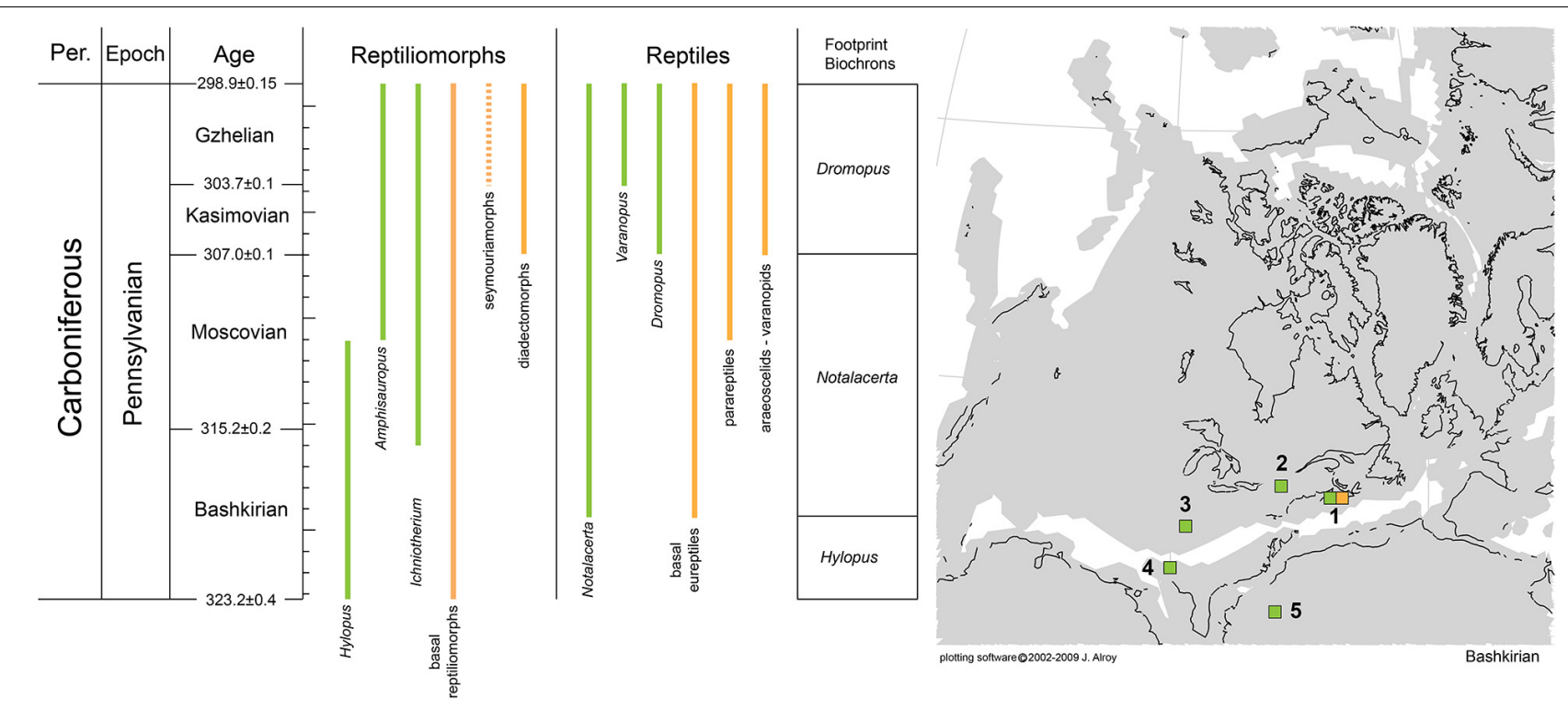

FIGURE 11 | Biostratigraphic ranges of anamniote reptiliomorphs and reptiles during the Carboniferous and paleobiogeography of reptiles during the Bashkirian. Skeletons in orange and ichnotaxa in green. Map from Alroy (2013), modified.

(Cisneros et al., 2020). Unfortunately, appendicular skeletons of these taxa are presently largely incomplete, so a track-trackmaker correlation based on morphofunctional features is currently not feasible. The oldest record of parareptile footprints is constituted by the ichnotaxon Varanopus microdactylus, found in the Gzhelian Wescogame Formation of Grand Canyon, Arizona, United States and the Gzhelian-Asselian Cape John Formation of Nova Scotia, Canada (Van Allen et al., 2005; Marchetti et al., 2020d). The trackmakers of Varanopus microdactylus include bolosaurian parareptiles. The oldest record of bolosaurian parareptiles is Erpetonyx arsenaultorum, described from the Gzhelian Egmont Bay Formation of Prince Edward Island, Canada (Modesto et al., 2015). So, the tetrapod footprint record of parareptiles expands the paleobiogeographic distribution of the group during the Gzhelian, encompassing areas from presentday Arizona and Nova Scotia, whereas skeletons are only known from Prince Edward Island.

The oldest araeoscelid diapsid reptile is Petrolacosaurus kansensis from the Stanton Formation of Kansas, United States, of Kasimovian age (Reisz, 1981). The oldest varanopid is Archaeovenator hamiltonensis from the Calhoun Shale, Shawnee Group of Kansas, dated as early Gzhelian (Reisz and Dilkes, 2003). We attribute the ichnotaxon Dromopus lacertoides to araeoscelids and non-varanodontine varanopids. Moreover, the ichnotaxon attributed to varanodontine varanopids, Tambachichnium schmidti, is morphologically similar to Dromopus lacertoides, while the ichnotaxon attributed to non-varanopid "pelycosaurs," Dimetropus leisnerianus, has a very different morphology from both. This is related to a markedly different pes and manus structure of the respective trackmaker groups, i.e., araeoscelids-varanopids and nonvaranopid "pelycosaurs." This result seems to be consistent with the recently proposed placement of varanopids within diapsid reptiles and outside synapsids (Ford and Benson, 2020), suggesting that pes and manus may include key characters for the phylogeny of these groups. The oldest footprint record of araeoscelids and non-varanodontine varanopids is Dromopus lacertoides from the Enville Member of the Salop Formation of England (Haubold and Sarjeant, 1973; Meade et al., 2016), dated as Kasimovian (Cleal, 2008). The other Carboniferous records of this ichnotaxon are Gzhelian, including occurrences from Kansas, Nova Scotia and Germany (Marsh, 1894; Van Allen et al., 2005; Voigt, 2012). Therefore, the oldest Dromopus lacertoides (Kasimovian of England) would be close to time equivalent with the appearance of the araeoscelid group (Kasimovian of Kansas). Moreover, the paleogeography of Dromopus lacertoides during the Gzhelian encompasses the United States, eastern Canada and central Europe, being much broader than the distribution of both varanopids and araeoscelids in the Gzhelian (United States), probably meaning that one or both of these groups radiated during the Gzhelian. The oldest varanodontine varanopid is Aerosaurus wellesi from the El Cobre Canyon Formation of New Mexico, late Gzhelian (e.g., Pellettier, 2014). We attribute this group of varanopids to the ichnotaxon Tambachichnium schmidti. Unfortunately, no Gzhelian records are known of these footprints, their stratigraphic distribution being limited to the CisuralianGuadalupian (e.g., Voigt and Lucas, 2018; Schneider et al., 2020; Lucas et al., 2021).

\section{DATA AVAILABILITY STATEMENT}

The original contributions presented in the study are included in the article/Supplementary Material, further inquiries can be directed to the corresponding author/s. 


\section{AUTHOR CONTRIBUTIONS}

LM ideated the study, analyzed the data, and provided measurements. LM, SV, SL, DF, MS, and OK collected the data and worked on ichnotaxonomy. LM, MM, and JF worked on track-trackmaker correlation. $\mathrm{MB}$ performed the multivariate analysis on tetrapod footprint parameters. LM, SV, SL, and JC compiled the stratigraphy of the fossiliferous units. LM and $\mathrm{MB}$ worked on figures and tables. All authors wrote and revised the manuscript.

\section{FUNDING}

LM, MM, and JF were funded by the German Federal Ministry of Education and Research (BMBF) for the BROMACKER Project 2020-2025. MS acknowledges the support of the Natural Sciences and Engineering Research Council of Canada (NSERC) (funding reference number 547631). MS and OK acknowledge Kathleen Thorne and Serge Allard for their financial support for this and other projects provided by the New Brunswick Geological Survey's Branch Research Grant. OK would like to

\section{REFERENCES}

Aldrich, T. H. Sr., and Jones, W. B. (1930). Footprints from the coal measures of Alabama. Geol. Surv. Alabama Museum Paper 9, 1-64.

Alroy, J. (2013). Online Paleogeographic Map Generator. Available online at: http: //paleodb.org/?a=mapForm (accessed February 23, 2021).

Baird, D. (1952). Revision of the Pennsylvanian and Permian footprints Limnopus, Allopus and Baropus. J. Paleontol. 26, 832-840.

Baird, D. (1982). "Upper Pennsylvanian ichnology of Kansas city, Missouri”, in Ichnology Newsletter, 13.

Berman, D. S., Henrici, A. C., Sumida, S. S., Martens, T., and Pelletier, V. (2014). "First European record of a varanodontine (Synapsida: Varanopidae): member of a unique Early Permian upland paleoecosystem, Tambach Basin, central Germany," in Early Evolutionary History of the Synapsida, eds F. Christian, C. F. Kammerer, D. Kenneth, K. D. Angielczyk, and J. Fröbisch (Dordrecht: Springer), 69-86. doi: 10.1007/978-94-007-6841-3_5

Berman, D. S., Reisz, R. R., Scott, D., Henrici, A. C., Sumida, S. S., and Martens, T. (2000). Early Permian bipedal reptile. Science 290, 969-972. doi: 10.1126/ science.290.5493.969

Buchwitz, M., and Voigt, S. (2018). On the morphological variability of Ichniotherium tracks and evolution of locomotion in the sistergroup of amniotes. PeerJ. 6:e4346. doi: 10.7717/peerj.4346

Buchwitz, M., Jansen, M., Renaudie, J., Marchetti, L., and Voigt, S. (2021). Evolutionary change in locomotion close to the origin of amniotes inferred from trackway data in an ancestral state reconstruction approach. Front. Ecol. Evol. 9:674779. doi: 10.3389/fevo.2021.674779

Butts, E. (1891). Recently discovered footprints of the amphibian age in the Upper Coal Measure Group of Kansas City. Missouri. Kansas City Sci. 5, 17-19.

Calder, J. H., Gibling, M. R., Scott, A. C., Davies, S. J., Hebert, B. L., Greb, S. F., et al. (2006). A fossil lycopsid forest succession in the classic Joggins section of Nova Scotia: paleoecology of a disturbance-prone Pennsylvanian wetland. Special Papers Geol. Soc. Am. 399, 169-195.

Carrano, M. T., and Wilson, J. A. (2001). Taxon distributions and the tetrapod track record. Paleobiology 27, 564-582. doi: 10.1666/0094-8373(2001)027<0564: tdattt $>2.0 . \operatorname{co} ; 2$

Carroll, R. L. (1964). The earliest reptiles. Zool. J. Linnean Soc. 45, 61-83. doi: 10.1111/j.1096-3642.1964.tb00488.x

Carroll, R. L. (1969). A Middle Pennsylvanian captorhinomorph, and the interrelationships of primitive reptiles. J. Paleontol. 43, 151-170. thank the Geological Survey of Canada (Dr. Denis Lavoie) for providing graduate school funding during the preparation of this manuscript.

\section{ACKNOWLEDGMENTS}

We would like to thank all the curators and collection managers who helped for the study of the collections. MS and OK thank Nancy Jacque, David Wagner, Christopher Taylor, and Marion Homer for their moral and financial support during the writing of this manuscript. Steven Hinds and Adrian Park are thanked for insightful discussions related to the New Brunswick Geological Context. We thank the reviewers MJB and JL for the helpful discussion.

\section{SUPPLEMENTARY MATERIAL}

The Supplementary Material for this article can be found online at: https://www.frontiersin.org/articles/10.3389/fevo.2021. 696511/full\#supplementary-material

Carroll, R. L., and Baird, D. (1972). Carboniferous stem-reptiles of the family Romeriidae. Bull. Museum Comp. Zool. 143, 321-361.

Chesnut, D. R. Jr., Baird, D., Smith, J. H., and Lewis, R. Q. Sr. (1994). Reptile trackway from the Lee Formation (Lower Pennsylvanian) of south-central Kentucky. J. Paleontol. 68, 154-158. doi: 10.1017/s0022336000025671

Cisneros, J. C., Kammerer, C. F., Angielczyk, K. D., Fröbisch, J., Marsicano, C., Smith, R. M., et al. (2020). A new reptile from the lower Permian of Brazil (Karutia fortunata gen. et sp. nov.) and the interrelationships of Parareptilia. J. Syst. Palaeontol. 18, 1939-1959. doi: 10.1080/14772019.2020.1863487

Clack, J. A. (2002). An early tetrapod from 'Romer's Gap'. Nature 418, 72-76. doi: $10.1038 /$ nature 00824

Cleal, C. J. (2008). Westphalian-Stephanian macrofloras of the southern Pennines Basin. UK. Stud. Geol. Polonica 129, 25-41.

Colbert, E. H., and Schaeffer, B. (1947). Some Mississippian footprints from Indiana. Am. J. Sci. 245, 614-623. doi: 10.2475/ajs.245.10.614

Cotton, W., Hunt, A. P., and Cotton, J. (1995). "Paleozoic vertebrate tracksites in eastern North America," in Early Permian Footprints and Facies, eds S. G. Lucas and A. B. Heckert (Albuquerque, NM: New Mexico Museum of Natural History and Science Bulletin), 189-217.

Cox, E. T. (1874). Colletosaurus indianaensis Cox. Geological Survey of Indiana, Fifth Annual Report. 247-248.

Dawson, J. W. (1863). The Air-breathers of the coal period in Nova Scotia. Can. Nat. Geol. 8, 1-81.

Dawson, J. W. (1882). On the footprints of batrachians observed in the Carboniferous rocks of Nova Scotia. Trans. R. Soc. London 173, 651-654.

Didier, G., and Laurin, M. (2020). Exact distribution of divergence times from fossil ages and tree topologies. Syst. Biol. 69, 1068-1087. doi: 10.1093/sysbio/syaa021

Dilkes, D. (2014). Carpus and tarsus of Temnospondyli. Vertebrate Anatomy Morphol. Palaeontol. 1, 51-87. doi: 10.18435/ $5 \mathrm{mw} 2 \mathrm{q}$

Falcon-Lang, H. J., Benton, M. J., and Stimson, M. (2007). Ecology of earliest reptiles inferred from basal Pennsylvanian trackways. J. Geol. Soc. London 164, 1113-1118. doi: 10.1144/0016-76492007-015

Falcon-Lang, H. J., Gibling, M. R., Benton, M. J., Miller, R. F., and Bashforth, A. R. (2010). Diverse tetrapod trackways in the Lower Pennsylvanian Tynemouth Creek Formation, near St. Martin, southern New Brunswick, Canada. Palaeogeogr. Palaeoclimatol. Palaeoecol. 296, 1-13. doi: 10.1016/j. palaeo.2010.06.020

Fedak, T. J. (2021). Tracking the Fossil Footprints and Letters of Science from Doctor E. F. Nova Scotia: Harding in Windsor, 1842-1855. 
Fichman, M. E., Crespi, J. M., Getty, P. R., and Bush, A. M. (2015). Retrodeformation of Carboniferous trace fossils from the Narragansett Basin, United States, using raindrop imprints and bedding-cleavage intersection lineation as strain markers. Palaios 30, 574-588. doi: 10.2110/palo.2014.092

Fichter, J. (1982). Tetrapodenfährten aus dem Oberkarbon (Westfalium A und C) West- und Südwestdeutschlands. Mainzer Geowissenschaftliche Mitteilungen 11, 33-77.

Fichter, J. (1983). Tetrapodenfährten aus dem saarpfalzischen Rotliegenden (?Ober-Karbon-Unter-Perm; SW-Deutschland). Teil II: die Fährten der Gattungen Foliipes, Varanopus, Ichniotherium, Dimetropus, Palmichnus, cf. Chelichnus, cf. Laoporus und Anhomoiichnum. Mainzer Naturwissenschaftliches Archiv. 21, 125-186.

Fillmore, D. L., Lucas, S. G., and Simpson, E. L. (2012). Ichnology of the Mississippian Mauch Chunk Formation, eastern Pennsylvania. N. Mexico Museum Nat. History Sci. Bull. 54, 1-136.

Fillmore, D. L., Lucas, S. G., and Simpson, E. L. (2015). Vertebrate ichnofossils from coal mine tailings of the Pennsylvanian Llewellyn Formation, eastern Pennsylvania. N. Mexico Museum Nat. History Sci. Bull. 67, 33-42.

Ford, D. P., and Benson, R. B. (2020). The phylogeny of early amniotes and the affinities of Parareptilia and Varanopidae. Nat. Ecol. Evol. 4, 57-65. doi: 10.1038/s41559-019-1047-3

Gand, G. (1988). Les Traces de Vertébrés Tétrapodes du Permien français (Paléontologie, Stratigraphie, Paléoenvironnements). Doctoral dissertation, Dijon.

Gand, G., and Durand, M. (2006). Tetrapod footprint ichno-associations from French Permian basins. Comparisons with other Euramerican ichnofaunas. Geol. Soc. London 265, 157-177. doi: 10.1144/gsl.sp.2006.265.01.07

Geinitz, H. B. (1861). Dyas oder die Zechsteinformation und das Rothliegende (Permische Formation zum Theil). Leipzig: Wilhelm Engelmann, 130.

Glienke, S. (2015). Two new species of the genus Batropetes (Tetrapoda, Lepospondyli) from the Central European Rotliegend (basal Permian) in Germany. J. Vertebrate Paleontol. 35, e918041. doi: 10.1080/02724634.2014. 918041

Haubold, H. (1970). Versuch einer Revision der Amphibien-Fährten des Karbon und Perm. Freiberger Forschungshefte Reihe C, 260, 83-117.

Hammer, Ø, Harper, D. A. T., and Ryan, P. D. (2001). PAST: paleontological statistics software package for education and data analysis. Palaeontol. Electron. $4: 9$.

Haubold, H. (1971). Ichnia amphibiorum et reptiliorum fossilium. Encycl. Paleoherpetol. 18, 1-124.

Haubold, H. (1984). Saurierfährten. Die Neue Brehm-Bücherei. Wittenberg: Ziemsen-Verlag, 231.

Haubold, H. (1996). Ichnotaxonomie und Klassifikation von Tetrapodenfährten aus dem Perm. Hallesches Jahrbuch Geowissenschaften B 18, 23-88.

Haubold, H., Allen, A., Atkinson, T. P., Buta, R. J., Lacefield, J. A., Minkin, S. C., et al. (2005). Interpretation of the tetrapod footprints from the Early Pennsylvanian of Alabama. Pennsylvanian Footprints Black Warrior Basin Alabama 1, 75-111.

Haubold, H., and Lucas, S. G. (2001). Die Tetrapodenfährten der Choza Formation (Texas) und das Artinsk-Alter der Redbed-Ichnofaunen des Unteren Perm. Hallesches Jahrbuch Geowissenschaften B 23, 79-108.

Haubold, H., and Lucas, S. G. (2003). Tetrapod footprints of the lower Permian Choza Formation at Castle Peak, Texas. Paläontol. Zeitschrift 77, 247-261. doi: $10.1007 / \mathrm{bf} 03006940$

Haubold, H., and Sarjeant, W. A. S. (1973). Tetrapodenfährten aus den Keele und Enville groups (Permokarbon) von Shropshire und South Staffordshire, Grossbrittannien. Zeitschrift Geol. Wissenschaften Berlin 1, 895-933.

Haubold, H., Hunt, A. P., Lucas, S. G., and Lockley, M. G. (1995). "Wolfcampian (Early Permian) vertebrate tracks from Arizona and New Mexico," in Early Permian Footprints and Facies, eds S. G. Lucas and A. B. Heckert (Albuquerque, NM: New Mexico Museum of Natural History and Science Bulletin), 135-165.

Holmes, R. B. (1984). The Carboniferous amphibian Proterogyrinus scheelei Romer, and the early evolution of tetrapods. Philosophical Trans. R. Soc. London B 306, 431-527. doi: 10.1098/rstb.1984. 0103

Holmes, R. B. (2003). The hind limb of Captorhinus aguti and the step cycle of basal amniotes. Can. J. Earth Sci. 40, 515-526. doi: 10.1139/e02-039
ICZN (1999). International Code of Zoological Nomenclature, 4th Edn. London: International Trust for Zoological Nomenclature.

Keighley, D. G., and Pickerill, R. K. (1998). Systematic ichnology of the nonmarine Mabou and Cumberland groups (Carboniferous), of western Cape Breton Island, eastern Canada. 2: Surface markings. Atlantic Geol. 34, 83-112.

Keighley, D. G., Calder, J. H., Park, A. F., Pickerill, R. K., Waldron, J. W., FalconLang, H. J., et al. (2008). Discussion on ecology of earliest reptiles inferred from basal Pennsylvanian trackways. J. Geol. Soc. 165, 983-987. doi: 10.1144/001676492008-045

Kissel, R. A., and Lehman, T. M. (2002). Upper Pennsylvanian tetrapods from the Ada Formation of Seminole County, Oklahoma. J. Paleontol. 76, 529-545. doi: 10.1666/0022-3360(2002)076<0529:uptfta > 2.0.co;2

Klembara, J., and Ruta, M. (2003). The seymouriamorph tetrapod Utegenia shpinari from the ? Upper Carboniferous-lower Permian of Kazakhstan. Part I: cranial anatomy and ontogeny. Earth Environ. Sci. Trans. R. Soc. Edinburgh 94, 45-74. doi: 10.1017/s0263593303000038

Kümmell, S. B., and Frey, E. (2012). Digital arcade in the autopodia of Synapsida: standard position of the digits and dorsoventral excursion angle of digital joints in the rays II-V. Palaeobiodiversity Palaeoenviron. 92, 171-196. doi: 10.1007/ s12549-012-0076-6

Lagnaoui, A., Voigt, S., Saber, H., and Schneider, J. W. (2014). First occurrence of tetrapod footprints from Westphalian strata of the Sidi Kassem Basin, Central Morocco. Ichnos 21, 223-233. doi: 10.1080/10420940.2014.955096

Lea, I. (1849). On reptilian footmarks found in the gorge of Sharp Mountain near Pottsville, Pennsylvania. Proc. Am. Philosophical Soc. 5, 91-94.

Lee, M. S. Y. (1997). The evolution of the reptilian hindfoot and the homology of the hooked fifth metatarsal. J. Evol. Biol. 10, 253-263. doi: 10.1046/j.1420-9101. 1997.10020253.x

Leonardi, G. (1987). Glossary and Manual of Tetrapod Footprint Palaeoichnology. Brasilia: Departamento Nacional de Producão Mineral, 75.

Lucas, S. G. (2018). Permian tetrapod biochronology, correlation and evolutionary events. Geol. Soc. London 450, 405-444. doi: 10.1144/sp450.12

Lucas, S. G. (2019). An ichnological perspective on some major events of Paleozoic tetrapod evolution. Bolletino Soc. Paleontol. Italiana 58, 223-266.

Lucas, S. G., Fillmore, D. L., and Simpson, E. L. (2010). The Mississippian tetrapod footprint ichnogenus Palaeosauropus: extramorphological variation and ichnotaxonomy. Ichnos 17, 177-186. doi: 10.1080/10420940.2010.502492

Lucas, S. G., Lerner, A. J., Bruner, M., and Shipman, P. (2004). Middle Pennsylvanian ichnofauna from eastern Oklahoma, USA. Ichnos 11, 45-55. doi: 10.1080/10420940490442322

Lucas, S. G., Stimson, M. R., King, O. A., Calder, J. H., Mansky, C. F., Hebert, B. L., et al. (2021). Carboniferous Tetrapod Footprint Biostratigraphy, Biochronology and Evolutionary Events. London: Geological Society, Special Publications, 512. doi: 10.1144/SP512-2020-235

Lucas, S. G., Voigt, S., Lerner, A. J., and Nelson, W. J. (2011). Late early Permian continental ichnofauna from Lake Kemp, north-central Texas, USA. Palaeogeogr. Palaeoclimatol. Palaeoecol. 308, 395-404. doi: 10.1016/j.palaeo. 2011.05.047

Mann, A., McDaniel, E. J., McColville, E. R., and Maddin, H. C. (2019). Carbonodraco lundi gen et sp. nov., the oldest parareptile, from Linton, Ohio, and new insights into the early radiation of reptiles. R. Soc. Open Sci. 6:191191. doi: 10.1098/rsos.191191

Mansky, C. F., and Lucas, S. G. (2013). Romer's Gap revisited: continental assemblages and ichno-assemblages from the basal Carboniferous of Blue Beach, Nova Scotia, Canada. N. Mexico Museum Nat. History Sci. Bull. 60, 244-273.

Marchetti, L. (2016). New occurrences of tetrapod ichnotaxa from the Permian Orobic Basin (Northern Italy) and critical discussion of the age of the ichnoassociation. Papers Palaeontol. 2, 363-386. doi: 10.1002/spp2.1045

Marchetti, L., Belvedere, M., Voigt, S., Klein, H., Castanera, D., Díaz-Martínez, I., et al. (2019a). Defining the morphological quality of fossil footprints. Problems and principles of preservation in tetrapod ichnology with examples from the Palaeozoic to the present. Earth Sci. Rev. 193, 109-145. doi: 10.1016/j.earscirev. 2019.04.008

Marchetti, L., Francischini, H., Lucas, S. G., Voigt, S., Hunt, A. P., and Santucci, V. L. (2020d). Paleozoic Vertebrate Ichnology of Grand Canyon National Park. Grand Canyon National Park: Centennial Paleontological Resource Inventory (Non-Sensitive Version). Natural Resource Report 
NPS/GRCA/NRR--2020/2103. Fort Collins, CO: National Park Service, 333-379.

Marchetti, L., Klein, H., Buchwitz, M., Ronchi, A., Smith, R. M., De Klerk, W. J., et al. (2019b). Permian-Triassic vertebrate footprints from South Africa: ichnotaxonomy, producers and biostratigraphy through two major faunal crises. Gondwana Res. 72, 139-168. doi: 10.1016/j.gr.2019.03.009

Marchetti, L., Mujal, E., and Bernardi, M. (2017). An unusual Amphisauropus trackway and its implication for understanding seymouriamorph locomotion. Lethaia 50, 162-174. doi: 10.1111/let.12184

Marchetti, L., Muscio, G., Petti, F. M., Pillola, G. L., and Zoboli, D. (2020c). The Carboniferous tetrapod ichnoassociation from Italy. J. Mediterranean Earth Sci. 12, 31-39.

Marchetti, L., Ronchi, A., Santi, G., and Voigt, S. (2015a). The Gerola Valley site (Orobic Basin, Northern Italy): a key for understanding late early Permian tetrapod ichnofaunas. Palaeogeogr. Palaeoclimatol. Palaeoecol. 439, 97-116. doi: 10.1016/j.palaeo.2015.02.032

Marchetti, L., Ronchi, A., Santi, G., Schirolli, P., and Conti, M. A. (2015b). Revision of a classic site for Permian tetrapod ichnology (Collio Formation, Trompia and Caffaro valleys, N. Italy), new evidences for the radiation of captorhinomorph footprints. Palaeogeogr. Palaeoclimatol. Palaeoecol. 433, 140-155. doi: 10.1016/ j.palaeo.2015.04.005

Marchetti, L., Voigt, S., Lucas, S. G., Francischini, H., Dentzien-Dias, P., Sacchi, R., et al. (2019c). Tetrapod ichnotaxonomy in eolian paleoenvironments (Coconino and De Chelly formations, Arizona) and late Cisuralian (Permian) sauropsid radiation. Earth Sci. Rev. 190, 148-170. doi: 10.1016/j.earscirev.2018. 12.011

Marchetti, L., Voigt, S., Lucas, S. G., Stimson, M. R., King, O. A., and Calder, J. H. (2020a). Footprints of the earliest reptiles: Notalacerta missouriensis-Ichnotaxonomy, potential trackmakers, biostratigraphy, palaeobiogeography and palaeoecology. Ann. Soc. Geologorum Poloniae 90, 271-290.

Marchetti, L., Voigt, S., Mujal, E., Lucas, S. G., Francischini, H., Fortuny, J., et al. (2020b). Extending the footprint record of Pareiasauromorpha to the Cisuralian: earlier appearance and wider palaeobiogeography of the group. Papers Palaeontol. 1-23. doi: 10.1002/spp2.1342

Marsh, O. C. (1894). Footprints of vertebrates in the Coal Measures of Kansas. Am. J. Sci. 348, 81-84. doi: 10.2475/ajs.s3-48.283.81

Matthew, G. (1904). Note on the genus Hylopus of Dawson. Bull. Nat. History Soc. New Brunswick 5, 247-252.

Matthew, G. F. (1903). New genera of batrachian footprints from the Carboniferous system in eastern Canada. Can. Record Sci. 9, 99-111.

Meade, L. E., Jones, A. S., and Butler, R. J. (2016). A revision of tetrapod footprints from the late Carboniferous of the West Midlands, UK. PeerJ. 4:e2718. doi: $10.7717 /$ peerj. 2718

Mietto, P., Muscio, G., and Venturini, C. (1986). Impronte di tetrapodi nei terreni carboniferi delle Alpi Carniche. Gortania Atti Museo Friulano Storia Naturale 7, 59-73.

Modesto, S. P., Scott, D. M., MacDougall, M. J., Sues, H. D., Evans, D. C., and Reisz, R. R. (2015). The oldest parareptile and the early diversification of reptiles. Proc. R. Soc. B Biol. Sci. 282:20141912. doi: 10.1098/rspb.2014.1912

Moodie, R. L. (1929). Vertebrate footprints from the red beds of Texas. Am. J. Sci. 100, 352-368. doi: 10.2475/ajs.s5-17.100.352

Moodie, R. L. (1930). Vertebrate footprints from the Red Beds of Taxas II. J. Geolol. 38, 548-565. doi: 10.1086/623755

Mossman, D. J., and Grantham, R. G. (2000). Vertebrate trackways in the Parrsboro Formation (upper Carboniferous) at Rams Head. Cumberland County Nova Scotia Atlantic Geol. 35, 185-196.

Mossman, D. J., and Grantham, R. G. (2008). Eochelysipus horni, a new vertebrate trace fossil from the Tournaisian Horton Bluff Formation. Nova Scotia Atlantic Geol. 44, 69-77. doi: 10.4138/5933

Mujal, E., and Marchetti, L. (2020). Ichniotherium tracks from the Permian of France, and their implications for understanding the locomotion and palaeobiogeography of large diadectomorphs. Palaeogeogr. Palaeoclimatol. Palaeoecol. 547:109698. doi: 10.1016/j.palaeo.2020.109698

Mujal, E., Marchetti, L., Schoch, R. R., and Fortuny, J. (2020). Upper Paleozoic to Lower Mesozoic tetrapod ichnology revisited: photogrammetry and relative depth pattern inferences on functional prevalence of autopodia. Front. Earth Sci. 8:248. doi: 10.3389/feart.2020.00248
Müller, A. H. (1954). Zur Ichnologie und Stratonomie des Oberrotliegenden von Tambach (Thüringen). Paläontol. Zeitschrift 28, 189-203. doi: 10.1007/ bf03041864

Müller, J., Berman, D. S., Henrici, A. C., Martens, T., and Sumida, S. S. (2006). The basal reptile Thuringothyris mahlendorffae (Amniota: Eureptilia) from the Lower Permian of Germany. J. Palaeontol. 80, 726-739. doi: 10.1666/00223360(2006)80[726:TBRTMA]2.0.CO;2

Niedźwiedzki, G. (2015). Carboniferous tetrapod footprints from the Lublin Basin. SE Poland. GFF 137, 57-65. doi: 10.1080/11035897.2014.945618

Nopcsa, F. (1923). Die Familien der Reptilien. Fortschritte Geologie Paläontol. 2, $1-210$.

Pabst, W. (1896). Thierfährten aus dem Oberrothliegenden von Tambach in Thüringen. Zeitschrift Deutschen Geol. Gesellschaft 48, 638-643.

Pardo, J. D., Lennie, K., and Anderson, J. S. (2020). Can we reliably calibrate deep nodes in the tetrapod tree? Case studies in deep tetrapod divergences. Front. Genet. 11:1159. doi: 10.3389/fgene.2020.506749

Paton, R. L., Smithson, T. R., and Clack, J. A. (1999). An amniote-like skeleton from the Early Carboniferous of Scotland. Nature 398, 508-513. doi: 10.1038/19071

Peabody, F. E. (1948). Reptile and amphibian trackways from the Lower Triassic Moenkopi formation of Arizona and Utah. Univ. California Dep. Geol. Sci. Bull. 27, 295-468.

Pellettier, V. (2014). "Postcranial description and reconstruction of the varanodontine varanopid Aerosaurus wellesi (Synapsida: Eupelycosauria)," in Early Evolutionary History of the Synapsida, eds F. Christian, C. F. Kammerer, D. Kenneth, K. D. Angielczyk, and J. Fröbisch (Dordrecht: Springer), 53-68. doi: 10.1007/978-94-007-6841-3_4

Pohlig, H. (1892). “Altpermische Saurierfährten, Fische und Medusen der Gegend von Friedrichroda i. Thüringen," in Festschrift Geburtstag von Rudolf Leuckardt, Vol. 70, ed. ANON (Leipzig: Engelmann), 59-64.

Reisz, R. R. (1981). A diapsid reptile from the Pennsylvanian of Kansas. Univ. Kansas Publications Museum Nat. History 7, 1-74.

Reisz, R. R. (1990). "Geology and paleontology of the Garnett quarry," in 1990 Society of Vertebrate Paleontology Upper Paleozoic of Eastern Kansas Excursion Guidebook. Lawrence, KS: Kansas Geological Survey, Vol. 24, eds C. Cunningham and C. G. Maples 43-48.

Reisz, R. R., and Dilkes, D. W. (2003). Archaeovenator hamiltonensis, a new varanopid (Synapsida: Eupelycosauria) from the upper Carboniferous of Kansas. Can. J. Earth Sci. 40, 667-678. doi: 10.1139/e02-063

Reisz, R. R., Berman, D. S., and Scott, D. (1984). The anatomy and relationships of the lower Permian reptile Araeoscelis. J. Vertebrate Paleontol. 4, 57-67. doi: 10.1080/02724634.1984.10011986

Ruta, M., and Coates, M. I. (2007). Dates, nodes and character conflict: addressing the lissamphibian origin problem. J. Syst. Palaeontol. 5, 69-122. doi: 10.1017/ s1477201906002008

Ruta, M., Coates, M. I., and Quicke, D. L. (2003). Early tetrapod relationships revisited. Biol. Rev. 78, 251-345. doi: 10.1017/s1464793102006103

Ryan, R. J., Boehner, R. C., and Calder, J. H. (1991). Lithostratigraphic revisions of the upper Carboniferous to lower Permian strata in the Cumberland Basin, Nova Scotia and the regional implications for the Maritimes Basin in Atlantic Canada. Bull. Can. Petroleum Geol. 39, 289-314.

Sarjeant, W. A. S. (1971). Vertebrate tracks from the Permian of Castle Peak, Texas. Texas J. Sci. 22, 344-366.

Sarjeant, W. A. S., and Mossman, D. J. (1978). Vertebrate footprints from the Carboniferous sediments of Nova Scotia: a historical review and description of newly discovered forms. Palaeogeogr. Palaeoclimatol. Palaeoecol. 23, 279-306. doi: 10.1016/0031-0182(78)90097-4

Schmidt, H. (1956). Die große Bochumer Oberkarbon-Fährte. Paläontol. Zeitschrift 30, 199-206. doi: 10.1007/bf03041784

Schneider, J. W., Lucas, S. G., Scholze, F., Voigt, S., Marchetti, L., Klein, H., et al. (2020). Late Paleozoic-early Mesozoic continental biostratigraphy-links to the standard global chronostratigraphic scale. Palaeoworld 29, 186-238. doi: 10.1016/j.palwor.2019.09.001

Selwyn, A. R. (1872). IV.-On the discovery of reptilian footprints in Nova Scotia. Geol. Magazine 9, 250-251. doi: 10.1017/s0016756800465040

Spindler, F., Werneburg, R., and Schneider, J. W. (2019). A new mesenosaurine from the lower Permian of Germany and the postcrania of Mesenosaurus: implications for early amniote comparative osteology. Paläontol. Zeitschrift 93, 303-344. doi: 10.1007/s12542-018-0439-z 
Spindler, F., Werneburg, R., Schneider, J. W., Luthardt, L., Annacker, V., and Rößler, R. (2018). First arboreal 'pelycosaurs' (Synapsida: Varanopidae) from the early Permian Chemnitz Fossil Lagerstätte, SE Germany, with a review of varanopid phylogeny. Paläontol. Zeitschrift 92, 315-364. doi: 10.1007/s12542018-0405-9

Sternberg, C. M. (1933). Carboniferous tracks from Nova Scotia. Bull. Geol. Soc. Am. 44, 951-964. doi: 10.1130/gsab-44-951

Sumida, S. S. (1989). The appendicular skeleton of the Early Permian genus Labidosaurus (Reptilia, Captorhinomorpha, Captorhinidae) and the hind limb musculature of captorhinid reptiles. J. Vertebr. Paleontol. 9, 295-313. doi: 10. 1080/02724634.1989.10011764

Sundberg, F. A., Bennington, J. B., Wizevich, M. C., and Bambach, R. K. (1990). Upper Carboniferous (Namurian) amphibian trackways from the Bluefield Formation, West Virginia, USA. Ichnos 1, 111-124. doi: 10.1080/ 10420949009386340

Turek, V., Mikuláš, R., Libertín, M., and Jirásek, J. (2008). “Trace fossils from the upper Carboniferous fluvial sediments of the Intra-Sudetic Basin, Czech Republic," in Faunas and Palaeoenvironments of the Late Palaeozoic, Special Publication to 5th Symposium on Permo-Carboniferous Faunas, eds S. Štamberg and J. Zajíc (Hradec Králové: Museum of Eastern Bohemia), 38.

Utting, J., Giles, P. S., and Dolby, G. (2010). Palynostratigraphy of Mississippian and Pennsylvanian rocks, Joggins area, Nova Scotia and New Brunswick, Canada. Palynology 34, 43-89. doi: 10.1080/01916121003620569

Van Allen, H. E., Calder, J. H., and Hunt, A. P. (2005). The trackway record of a tetrapod community in a walchian conifer forest from the PermoCarboniferous of Nova Scotia. N.Mexico Museum Nat. History Sci. Bull. 30, $322-332$.

Voigt, S. (2005). Die Tetrapodenichnofauna des kontinentalen Oberkarbon und Perm im Thüringer Wald - Ichnotaxonomie, Paläoökologie und Biostratigraphie. Göttingen: Cuvillier Verlag, 305.

Voigt, S. (2007). Auf den Spuren der Saurier: die Tetrapodenfährten aus dem Oberkarbon und Unterperm des Saar- Nahe- Beckens. Kohlesümpfe Seen Halbwüsten Pollichia 10, 288-303.

Voigt, S. (2012). Tetrapodenfährten. Schriftenreihe Deutschen Gesellschaft Geowissenschaften 61, 92-106.

Voigt, S., and Ganzelewski, M. (2010). Toward the origin of amniotes: diadectomorph and synapsid footprints from the early late Carboniferous of Germany. Acta Palaeontol. Polonica 55, 57-72. doi: 10.4202/app.2009.0021

Voigt, S., and Haubold, H. (2015). Permian tetrapod footprints from the Spanish Pyrenees. Palaeogeogr. Palaeoclimatol. Palaeoecol. 417, 112-120.
Voigt, S., and Lucas, S. G. (2015). Permian tetrapod ichnodiversity of the Prehistoric Trackways National Monument (south-central New Mexico, USA). N. Mexico Museum Nat. History Sci. Bull. 65, 153-167.

Voigt, S., and Lucas, S. G. (2017). Early Permian tetrapod footprints from central New Mexico. N. Mexico Museum Nat. History Sci. Bull. 77, 333-352.

Voigt, S., and Lucas, S. G. (2018). Outline of a Permian tetrapod footprint ichnostratigraphy. Geol. Soc. London Special Publications 450, 387-404. doi: $10.1144 / \mathrm{sp} 450.10$

Voigt, S., Berman, D. S., and Henrici, A. C. (2007). First well-established track-trackmaker association of Paleozoic tetrapods based on Ichniotherium trackways and diadectid skeletons from the Lower Permian of Germany. J. Vertebrate Paleontol. 27, 553-570. doi: 10.1671/0272-4634(2007)27[553: fwtaop]2.0.co;2

Voigt, S., Lucas, S. G., Buchwitz, M., and Celeskey, M. D. (2013). Robledopus macdonaldi, a new kind of basal eureptile footprint from the early Permian of New Mexico. N. Mexico Museum Nat. History Sci. Bull. 60, 445-459.

Voigt, S., Schindler, T., Thum, H., and Fischer, J. (2019). "Field trip C2: Pennsylvanian-Permian of the Saar-Nahe Basin, SW Germany," in Proceedings of the 19th International Congress on the Carboniferous and Permian, Cologne July 29-August 2 2019. Field Guides. Kölner Forum Geol. Paläont, Vol. 24, eds H. Herbig, M. Aretz, M. R. W. Amler, and S. Hartenfels 217-250.

Vrazo, M. B., Benton, M. J., and Daeschler, E. B. (2007). Tetrapod tracks from the Mauch Chunk Formation (Middle to Upper Mississippian) of Pennsylvania, USA. Proc. Acad. Nat. Sci. Philadelphia 156, 199-209. doi: 10.1635/00973157(2007)156[199:ttftmc]2.0.co;2

Wood, N. J., and Miller, R. F. (2007). A Mississippian trackway (Pseudobradypus ichnosp.) from the Enragé Formation, New Brunswick, Canada. Atlantic Geol. 43, 180-186. doi: $10.4138 / 5648$

Conflict of Interest: The authors declare that the research was conducted in the absence of any commercial or financial relationships that could be construed as a potential conflict of interest.

Copyright (C) 2021 Marchetti, Voigt, Buchwitz, MacDougall, Lucas, Fillmore, Stimson, King, Calder and Fröbisch. This is an open-access article distributed under the terms of the Creative Commons Attribution License (CC BY). The use, distribution or reproduction in other forums is permitted, provided the original author(s) and the copyright owner(s) are credited and that the original publication in this journal is cited, in accordance with accepted academic practice. No use, distribution or reproduction is permitted which does not comply with these terms. 